\title{
Nitrogen Sources and Iron Availability Affect Pigment Biosynthesis and Nutrient Consumption in Anabaena sp. UTEX 2576
}

\author{
Daniel A. Norena-Caro (D), Tara M. Malone and Michael G. Benton *
}

Citation: Norena-Caro, D.A.;

Malone, T.M.; Benton, M.G. Nitrogen Sources and Iron Availability Affect Pigment Biosynthesis and Nutrient Consumption in Anabaena sp. UTEX 2576. Microorganisms 2021, 9, 431. https://doi.org/10.3390/ microorganisms 9020431

Academic Editor: Hitoshi Miyasaka

Received: 6 January 2021

Accepted: 16 February 2021

Published: 19 February 2021

Publisher's Note: MDPI stays neutral with regard to jurisdictional claims in published maps and institutional affiliations.

Copyright: (c) 2021 by the authors. Licensee MDPI, Basel, Switzerland. This article is an open access article distributed under the terms and conditions of the Creative Commons Attribution (CC BY) license (https:/ / creativecommons.org/licenses/by/ $4.0 /)$.
Cain Department of Chemical Engineering, 3307 Patrick F. Taylor Hall, Louisiana State University and A\&M College, Baton Rouge, LA 70803, USA; dnoren1@lsu.edu (D.A.N.-C.); tmalon5@lsu.edu (T.M.M.)

* Correspondence: benton@1su.edu; Tel.: +1-225-578-3056

\begin{abstract}
Anabaena sp. UTEX 2576 metabolizes multiple nitrogen (N) sources and is deemed a biotechnological platform for chemical production. Cyanobacteria have been identified as prolific producers of biofertilizers, biopolymers, biofuels, and other bioactive compounds. Here, we analyze the effect of different $\mathrm{N}$-sources and Fe availability on the bioproduction of phycobiliproteins and $\beta$ carotene. We characterize nutrient demand in modified BG11 media, including data on $\mathrm{CO}_{2}$ fixation rates, N-source consumption, and mineral utilization (e.g., phosphorus (P), and 11 metallic elements). Results suggest that non-diazotrophic cultures grow up to $60 \%$ faster than diazotrophic cells, resulting in $20 \%$ higher $\mathrm{CO}_{2}$-fixation rates. While the production of $\beta$-carotene was maximum in medium with $\mathrm{NaNO}_{3}, \mathrm{Fe}$ starvation increased the cellular abundance of $\mathrm{C}$-phycocyanin and allophycocyanin by at least $22 \%$. Compared to cells metabolizing $\mathrm{NaNO}_{3}$ and $\mathrm{N}_{2}$, cultures adapted to urea media increased their $\mathrm{P}$, calcium and manganese demands by at least $72 \%, 97 \%$ and $76 \%$, respectively. Variations on pigmentation and nutrient uptake were attributed to changes in phycocyanobilin biosynthesis, light-induced oxidation of carotenoids, and urea-promoted peroxidation. This work presents insights into developing optimal Anabaena culture for efficient operations of bioproduction and wastewater bioremediation with cyanobacteria.
\end{abstract}

Keywords: cyanobacteria; $\beta$-carotene; phycobiliproteins; oxidative stress; metal homeostasis; mineral media

\section{Introduction}

Chemical production by cyanobacteria has gained interest for carbon dioxide $\left(\mathrm{CO}_{2}\right)$ bio-sequestration applications. In this regard, most $\mathrm{CO}_{2}$ transformation studies have focused on the production of biofuels and commodities derived from the cyanobacterial central carbon metabolism [1]. Nevertheless, recent evidence indicates that feasible largescale cyanobacterial biotechnology should not only focus on biofuel production, but also on synthesis of biofertilizers, biopolymers, pigments, antioxidants, vitamins, and secondary metabolites [2,3]. From this perspective, the biotechnological importance of Anabaena sp. UTEX 2576 (a.k.a., Nostoc sp. PCC 7120 and, henceforth, Anabaena) is enhanced when considering their ability to utilize different nitrogen sources (N-sources) to fuel photosynthetic biosynthesis.

Although $\mathrm{CO}_{2}$ fixation is the most attractive feature of cyanobacterial metabolism, their global metabolic network is also affected by the N-source and iron (Fe) concentration in the growth medium, especially for $\mathrm{N}_{2}$-fixing species like Anabaena [4-7]. While the N-source is used for synthesizing proteins, nucleic acids, co-factors, and secondary metabolites [8], Fe is essential for the synthesis of DNA and iron-sulfur proteins [9]. Given that iron-sulfur proteins are involved in photosynthesis and $\mathrm{N}$ assimilation, cyanobacterial cells demand at least 10 times more Fe than non-photosynthetic bacteria like Escherichia coli $[10,11]$. In addition, Fe requirements of diazotrophic species like Anabaena are even higher compared to non- $\mathrm{N}_{2}$-fixing cyanobacteria [12]. 
Fe is essential for bacterial metabolism and is also the most important transition metal added to the cyanobacterial growth media $[13,14]$. However, excessive illumination conditions trigger Fe-catalyzed formation of reactive oxygen species (ROS) like superoxide $\left(\mathrm{O}_{2}{ }^{-}\right)$and hydrogen peroxide $\left(\mathrm{H}_{2} \mathrm{O}_{2}\right)$ during photosynthesis $[10,15,16]$. Therefore, Fe plays a contradictory role in cyanobacterial metabolism, both as a nutrient and catalyzer of damaging oxidative reactions. To deal with this paradox, cyanobacteria have evolved Fe homeostasis mechanisms mediated by ferric uptake regulator proteins (FUR) [9]. Although the FUR proteins are mainly responsible for maintaining the intracellular Fe balance in cyanobacterial cells, they are also crucial for keeping the balance of other essential metals like manganese (Mn), zinc ( $\mathrm{Zn})$, and nickel (Ni) [9,17-19]. The consumption of other important elements like phosphorus $(\mathrm{P})$, calcium $(\mathrm{Ca})$, magnesium $(\mathrm{Mg})$, boron $(\mathrm{B})$, molybdenum $(\mathrm{Mo})$, copper $(\mathrm{Cu})$, and cobalt $(\mathrm{Co})$ is not under the direct influence of FUR proteins $[4,5,9,20]$. However, the question of how Fe availability affects the consumption of these nutrients remains under study.

Cyanobacteria can grow in mineral media without any source of organic carbon (C) because they are autotrophic organisms, capable of oxygenic photosynthesis. The light phase of photosynthesis is facilitated by light-sensitive pigment-metalloprotein complexes that catalyze electron transfer reactions to produce ATP and NADPH. In cyanobacteria, such pigment-protein complexes are photosystem II (PSII, EC 1.10.3.9), photosystem I (PSI, EC 1.97.1.12) and phycobilisomes (PBSs), which are abundant in the thylakoid membranes. In PSII, a Mn-Ca based cluster $\left(\mathrm{Mn}_{4} \mathrm{CaO}_{5}\right)$ works in tandem with light-excited chlorophyll $a$ P680, pheophytin $a$, plastoquinone (PQ-9) and $\beta$-carotene to draw electrons from water, producing molecular Oxygen $\left(\mathrm{O}_{2}\right), \mathrm{O}_{2}{ }^{-}$and $\mathrm{H}_{2} \mathrm{O}_{2}$ [21-23]. Eventually, $\mathrm{O}_{2}{ }^{-}$and $\mathrm{H}_{2} \mathrm{O}_{2}$ are degraded by the action of superoxide dismutase (SOD, EC 1.15.1.1), and Mn-catalase (EC 1.11.1.6) $[10,24,25]$. In PSI, light-excited chlorophyll $a$ P700, phylloquinone (vitamin $\mathrm{K}_{1}$ ), $\beta$-carotene, and ferredoxins (iron-sulphur proteins), work together to transfer electrons from plastocyanin to $\mathrm{NADP}^{+}$, producing NADPH [26]. In a parallel transport reaction, the $\mathrm{H}^{+}$gradient generated across the thylakoid membranes fuels the production of ATP by ATP-synthase [27]. Cyanobacteria have developed PBSs to take advantage of a wider portion of the visible light spectrum for photosynthesis. PBSs are light-harvesting protein complexes, responsible for the cyanobacterial chromatic acclimation mechanism [28]. In Anabaena, these complexes are composed of multiple disc-shaped stacked subunits of phycobiliproteins (PBPs), forming large antenna-like structures of five inner cylinders and eight peripheral rods connected to the photosystems $[29,30]$. The distinctive PBP subunits of the Anabaena genus are C-phycocyanin (CPC, $\sim 35.8 \mathrm{kDa}$ ), phycoerythrocyanin (PEC, $\sim 35.7 \mathrm{kDa}$ ) and allophycocyanin (APC, $\sim 34.7 \mathrm{kDa}$ ) [31].

Although the main photosynthetic pigment in cyanobacteria is chlorophyll $a(\mathrm{Chl} a)$, a modified Mg-containing a chlorin ring with a side phytol chain, other auxiliary photosynthetic pigments are carotenoids and phycobilins [27,32]. The carotenoids are a group of isoprenoid compounds formed by different types of carotene (e.g., $\alpha$-carotene, $\beta$-carotene, $\gamma$-carotene, lycopene, torulene) and their oxygenated derivatives, the xanthophylls (e.g., echinenone, myxoxanthophyll, canthaxanthin, zeaxanthin) [33-35]. These compounds play multiple roles in photosynthetic organisms, participating in light-harvesting and defense mechanisms like energy dissipation under excess illumination, non-photochemical quenching, and photo-oxidation and lipid peroxidation protection [36,37]. While $\beta$-carotene is the most common carotenoid in the photosystems of Anabaena and other cyanobacteria $[23,26,33-35,38]$, echinenone, hydroxyechinenone, canthaxanthin, and zeaxanthin can be produced as a result of non-photochemical quenching. This occurs when $\beta$-carotene ketolase (EC 1.14.99.63) oxidizes $\beta$-carotene to counteract the damaging effect of ROS during oxidative stress, Fe surplus and deficit, and growth on urea [33,37,39-41]. The phycobilins are the chromophore molecules linked to the PBPs in cyanobacterial phycobilisomes. Chemically, these pigments are open-chain tertrapyrroles biosynthesized from heme and biliverdin $[42,43]$. Therefore, the synthesis of phycobilins is directly related with Chla production and Fe metabolism [12]. In Anabaena, the most important phycobilin 
pigments are phycocyanobilin (PCB) and phycoviolobilin (PVB), which are present in CPC, APC and PEC proteins. It has been demonstrated that Fe limitation leads to increased expression of furA gene, which encodes a master transcriptional regulator of Fe metabolism that also affects pigment biosynthesis [12,44].

Considering all the previous relationships, quantifying the impact of different Nsources and the Fe availability on the autotrophic metabolism of Anabaena is essential. Specifically, it is important to determine the impact of these nutrients on the growth kinetics and the bioproduction of valuable products of biotechnological interest like CPC, APC, PEC and $\beta$-carotene (pro-vitamin A), which are used in nutraceutical and cosmetic products as natural colorants, dietary supplements and anti-oxidant ingredients [45-47]. In addition, having a clearer understanding of the intricate relationship between $\mathrm{N}$ and Fe metabolism in photosynthetic microorganisms can provide useful insights to optimize culture media for large-scale operations with cyanobacteria $[3,48,49]$. The aim of this study is to quantify the effect of three different $\mathrm{N}$-sources, i.e., dinitrogen $\left(\mathrm{N}_{2}\right)$, nitrate $\left(\mathrm{NO}_{3}\right)$ and urea $\left(\mathrm{CH}_{4} \mathrm{~N}_{2} \mathrm{O}\right)$, and Fe availability on the production of $\beta$-carotene, Chla and PBPs, by Anabaena. Moreover, this work also discusses nutrient consumption kinetics and presents a novel approach for efficient quantification of $\mathrm{P}$ and metallic elements in BG11 mineral medium. This study provides a systemic analysis on the cultivation of Anabaena, taking into consideration the balance between nutrient demand and oxidative stress.

\section{Materials and Methods}

Additional methodology details are presented in the Supplementary Materials.

\subsection{Pre-Culture Conditions}

Anabaena sp. strain UTEX 2576 was consistently kept as an axenic $250 \mathrm{~mL}$ culture for more than 3 months in BG11(N $\left.{ }^{-}\right)$medium to preserve heterocyst differentiation. Axenic cultures were grown autotrophically $\left(75 \pm 7 \mu \mathrm{mol} \mathrm{m}{ }^{-2} \mathrm{~s}^{-1}\right)$ at $28{ }^{\circ} \mathrm{C}$ in an illuminated New Brunswick Innova 4340 incubator shaker (Edison, NJ, USA) at $130 \mathrm{rpm}$, with atmospheric $\mathrm{CO}_{2}$ concentration $\sim 410 \mathrm{ppm}$. Continuous shaking was necessary to promote air-exchange and atmospheric $\mathrm{CO}_{2}$ dissolution. New axenic cultures were prepared every week from the original culture. The formulation of BG11( $\left.\mathrm{N}^{-}\right)$is similar to standard BG11 medium, but it does not contain $\mathrm{NaNO}_{3}$ (See Supplementary Materials). The presence of heterocysts was periodically verified with optical and scanning electron microscopy (SEM). Because of their additional carbohydrate layer, heterocysts are larger than vegetative cells and their surface is more irregular [30]. A SEM picture of pre-cultured Anabaena filaments is presented in Figure S1. The conservation of $\mathrm{N}_{2}$-fixation ability was also easily verified because diazotrophic Anabaena are clumpier and their green coloration is darker than non-diazotrophic cultures (See Figure S5). Pre-cultures in BG11( $\mathrm{N}^{-}$) were used to prepare Anabaena pre-cultures with different N-sources. Pre-cultures in alternative media with $\mathrm{NaNO}_{3}$ and urea grew for at least one month before they were used to aseptically prepare the experimental cultures.

\subsection{Culture Conditions}

Anabaena was cultivated autotrophically at $28^{\circ} \mathrm{C}$ in an illuminated New Brunswick Innova 4340 incubator shaker at $130 \mathrm{rpm}$, with atmospheric $\mathrm{CO}_{2}$ (410 ppm) and sodium carbonate $(0.19 \mathrm{mM})$ as C-sources. Constant photosynthetic photon flux density (PPFD) of $75 \pm 7 \mu \mathrm{mol} \mathrm{m} \mathrm{m}^{-2} \mathrm{~s}^{-1}$ was provided with four $20 \mathrm{~W}$ white fluorescent light bulbs. Cultures were maintained in $500 \mathrm{~mL}$ glass Erlenmeyer flasks covered with foam plugs. The culture volume in each flask was $150 \mathrm{~mL}$. Growth media were variants of standard BG11 medium $[13,14]$. For convenience, media were named after the main N-source (e.g., BG11 ${ }_{\mathrm{N} 2}$, $B G 11_{\mathrm{NO} 3}$, and $\left.\mathrm{BG} 11_{\text {urea }}\right)$ in each culture type. Fresh $\mathrm{BG} 11_{\mathrm{NO} 3}$ contained $\mathrm{NaNO}_{3}(17.7 \mathrm{mM})$, BG11 urea contained urea $(3.0 \mathrm{mM})$ and $B G 11_{\mathrm{N} 2}$ lacked any significant $\mathrm{N}$-source to preserve heterocyst formation inherited from diazotrophic pre-cultures $[8,30]$. Soluble $\mathrm{Fe}^{3+}$ was supplied in the form of Ammonium ferric citrate $\left(\mathrm{Fe}^{3+}\right.$ as $\left.\mathrm{C}_{6} \mathrm{H}_{8} \mathrm{FeNO}_{7}\right)$, with starting Fe 
levels of $0.3 \mathrm{mg} / \mathrm{L}\left(5.4 \times 10^{-3} \mathrm{mM}\right), 1.2 \mathrm{mg} / \mathrm{L}(0.02 \mathrm{mM})$ and $5.0 \mathrm{mg} / \mathrm{L}(0.09 \mathrm{mM})$. Since the ferric substrate also contains ammonium, the Fe source adds a negligible amount of elemental $\mathrm{N}$ to the growth medium. Three independent biological replicates were prepared for each medium type and Fe level combination, for a total of 27 independent cultures. Additional details on growth media properties are presented in Tables S3 and S4. Considering the composition of each culture medium, the salinity varied from $0.3 \mathrm{~g} / \mathrm{L}$ (BG11 $1_{\mathrm{N} 2}$ and $\left.\mathrm{BG} 11_{\text {urea }}\right)$ to $1.8 \mathrm{~g} / \mathrm{L}\left(\mathrm{BG} 11_{\mathrm{NO} 3}\right)$.

\subsection{Measurement of Cellular Growth}

Cell reproduction was monitored by tracking the change on apparent absorbance at $730 \mathrm{~nm}\left(\mathrm{Abs}_{730}\right)$ every other day for two weeks. Abs 330 was routinely measured with a Beckman Coulter DU730 Life science ultraviolet (UV)-visible spectrophotometer. Given the filamentous nature of Anabaena, short 10-W sonication pulses (2 to $5 \mathrm{~s}$ ) were used to homogenize 1-1.5 mL culture samples prior to any $\mathrm{OD}_{730}$ measurement. A Fischer Scientific sonic dismembrator model 500 (Pittsburgh, PA, USA) was used to sonicate the liquid samples. Biomass generation was monitored using $\mathrm{Abs}_{730}$ measurements, cell densities, and dry biomass readings. Recorded $\mathrm{Abs}_{730}$ values were converted to cell density and biomass concentration using correlation equations for diazotrophic $\left(\mathrm{BG}_{\mathrm{N} 2}\right)$ and nondiazotrophic (BG11 ${ }_{\mathrm{NO} 3}$ and $B G 11_{\text {urea }}$ ) cultures (see Figure S2). Flow cytometry readings were performed in a BD Accuri C6flow cytometer (Ann Arbor, MI, USA), using a sample preparation protocol for filamentous cyanobacteria [50]. Biomass concentration (as dry cell weight of $10 \mathrm{~mL}$ of culture) was measured through filtration on Whatman $0.22 \mu \mathrm{m}$ cellulose nitrate membranes and vacuum drying at $90^{\circ} \mathrm{C}$ for $12 \mathrm{~h}$. The $\mathrm{Abs}_{730}$ at the beginning of each growth experiment was standardized at 0.1 to ensure starting cellular populations $\left(N_{\mathrm{o}}\right)$ between $6 \times 10^{5}$ and $8 \times 10^{5}$ cells $\mathrm{mL}^{-1}$. Cellular growth rates and generation times were determined after fitting $\mathrm{Abs}_{730}$ data to a saturation kinetic model [51].

\subsection{Extraction and Quantification of Phycobiliproteins (PBPS)}

PBPs were extracted from the cells by digesting with lysozyme. Briefly, a $1.5 \mathrm{~mL}-$ sample of cyanobacterial culture was centrifuged for $15 \mathrm{~min}$ at 15,000 RCF. The resulting pellet was resuspended in $1 \mathrm{~mL}$ of lysozyme solution $(2.7 \mathrm{mg} / \mathrm{mL}$ in TE buffer at $\mathrm{pH} 8.0)$ and sonicated for $10 \mathrm{~s}$ at $40 \mathrm{~W}$ with a Fischer Scientific sonic dismembrator model 500 . The cyanobacterial pellet was digested at $37^{\circ} \mathrm{C}$ for $8 \mathrm{~h}$ in a dry block incubator. During the digestion reaction, PBPs were released from the cells forming a blue extract. Lysed cells were separated from the extract after a second centrifugation step at 15,000 RCF for $15 \mathrm{~min}$. The concentration of PBPs in the blue extract was estimated from spectrophotometric readings at $570 \mathrm{~nm}$ for $\mathrm{PEC}, 620 \mathrm{~nm}$ for CPC, and $650 \mathrm{~nm}$ for APC using specific equations for Anabaena azollae [52]. Total concentration of PBPs was calculated as the sum of PEC, $\mathrm{CPC}$, and APC concentrations. Concentrations of PBPs were recorded every other day.

\subsection{Extraction and Quantification of Chlorophyll a (Chla), Total Carotenoids (CaroT) and $\beta$-Carotene}

Chlorophyll $a(\mathrm{Chl} a)$ and total carotenoids (CaroT) concentrations were determined every other day after solvent extraction with cold acetone. The concentration of Chla was calculated from the absorbance of the extract at $664 \mathrm{~nm}$ using Beer's law and an extinction coefficient of $87.67 \mathrm{~L} \mathrm{~g}^{-1} \mathrm{~cm}^{-1}$ [53].The same extract was analyzed to determine the concentration of CaroT (xanthophylls and carotenes) by measuring the absorbance at $470 \mathrm{~nm}$ and using an extinction coefficient of $250 \mathrm{~L} \mathrm{~g}^{-1} \mathrm{~cm}^{-1}$ [54,55].

The concentration of $\beta$-carotene and the ion abundances of other photosynthetic pigments (e.g., echinenone, pheophytin $a$, and chlorophyll $a$ ) were determined after extracting with cold methanol. These extracts were immediately analyzed after preparation with an Agilent 6230 Electrospray ionization Time-of-flight mass spectrometry (ESI-TOF MS) analyzer (Santa Clara, CA, USA). A $0.2 \mu \mathrm{L}$ - aliquot of methanol extract was injected to the MS analyzer and combined with a continuous stream $(0.4 \mathrm{~mL} / \mathrm{min})$ of $70 \% v / v$ acetonitrile and $30 \% v / v$ aqueous solution $\left(0.1 \% v / v\right.$ formic acid in water) at $30{ }^{\circ} \mathrm{C}$. Mass acquisition 
in positive mode covered a range from 100 to $3200 \mathrm{~m} / \mathrm{z}$, keeping a fragmentor voltage of $150 \mathrm{~V}$. The ion abundance of $\beta$-carotene was measured following the signal of the molecular ion $\left(\left[\mathrm{C}_{40} \mathrm{H}_{56}\right]^{+}, \mathrm{m} / \mathrm{z}=536.4382\right)$ [46]. A calibration curve relating $\beta$-carotene concentration in methanol extracts with the abundance of the molecular ion is presented in Figure S16. Ion abundance for echinenone was determined by observing the peak of the protonated molecule $\left(\left[\mathrm{C}_{40} \mathrm{H}_{54} \mathrm{O}+\mathrm{H}\right]^{+}, \mathrm{m} / \mathrm{z}=551.4253\right)$. Pheophytin $a$ and $\mathrm{Chl} a$ ion abundances were related to the signals of their protonated molecules: $\left[\mathrm{C}_{55} \mathrm{H}_{74} \mathrm{~N}_{4} \mathrm{O}_{5}+\mathrm{H}\right]^{+}, \mathrm{m} / \mathrm{z}=871.5737$ for pheophytin $a$ and $\left[\mathrm{C}_{55} \mathrm{H}_{74} \mathrm{MgN}_{4} \mathrm{O}_{5}+\mathrm{H}\right]^{+}, \mathrm{m} / \mathrm{z}=893.5431$ for Chl $a$. MS signals for pure methanol were subtracted from MS data recorded for methanolic extracts. See supporting information for additional details about solvent extraction procedures.

\subsection{Analysis of Mineral Elements with Inductively Coupled Plasma Optical Emission Spectroscopy (ICP-OES)}

Inductively coupled plasma optical emission spectroscopy (ICP-OES) was used for growth medium quality control and to track changes in the concentration of mineral elements in liquid media during cellular growth. A multi-element ICP-OES detection method based on the U.S. Environmental Protection Agency (EPA) 200.7 protocol was developed for efficient quantification of $\mathrm{B}, \mathrm{Na}, \mathrm{Mg}, \mathrm{P}, \mathrm{K}, \mathrm{Ca}, \mathrm{Mn}, \mathrm{Fe}, \mathrm{Co}, \mathrm{Ni}, \mathrm{Cu}, \mathrm{Zn}$ in fresh media and supernatants [56]. The minimum sample volume required for this analysis was $4 \mathrm{~mL}$. Optical emission was measured with a PerkinElmer Optima 8000 ICP-OES spectrometer (Waltham, MA, USA). Radio frequency power was $1500 \mathrm{~W}$ and plasma viewing was set to axial mode. Plasma, auxiliary gas and nebulizer gas flow rates were set to $8 \mathrm{~L} / \mathrm{min}, 0.2 \mathrm{~L} / \mathrm{min}$ and $0.7 \mathrm{~L} / \mathrm{min}$, respectively. Samples were analyzed at a flow rate of $1 \mathrm{~mL} / \mathrm{min}$, using $\mathrm{HNO}_{3} 5 \% v / v$ as washing fluid. Detection wavelengths were iterated to minimize spectral interference. The calibration standards were selected considering the composition of standard mineral BG11 medium [13]. Initial measurements conducted on liquid samples digested with $\mathrm{HNO}_{3} 2 \% v / v$ at $85^{\circ} \mathrm{C}$ demonstrated that acid digestion of cyanobacterial growth medium was not necessary. Calibration curves and detection wavelengths for each element are summarized in Figure S18. Concentrations of calibration standards are presented in Table S9.

\subsection{Measurement of Total Organic Carbon (TOC), N-Source Concentration and Urease Activity}

Total organic carbon (TOC) was measured using a commercial HACH high range total organic carbon reagent set (product \#2760445). The concentrations of sodium nitrate and urea were measured for cell-free supernatants and growth media to determine consumption profiles of these nutrients in $\mathrm{BG} 11_{\mathrm{NO} 3}$ and $\mathrm{BG} 11_{\text {urea }}$ media. The consumption rate of $\mathrm{N}_{2}$ in BG11 ${ }_{\mathrm{N} 2}$ (i.e., N2-fixation rate of diazotrophic Anabaena) was determined by measuring the total nitrogen $\left(\mathrm{N}_{\mathrm{T}}\right)$ content of cultures over time. Nitrate in $\mathrm{BG} 11_{\mathrm{NO}}$, urea in $\mathrm{BG} 11_{\text {urea }}$, and $\mathrm{N}_{\mathrm{T}}$ in $\mathrm{BG} 11_{\mathrm{N} 2}$ cultures were determined every other day from day zero to day 14 , for a total of eight sampling points per biological replicate. The urease activity was measured with a BioVision Urease activity kit (Milpitas, CA, USA) [57], after sample homogenization with sonic dismembration at $40 \mathrm{~W}$ (three cycles of $30 \mathrm{~s}$ on ice), following the manufacturer's instructions. Urease concentration in the lysed sample was determined with a Pierce BCA kit (Rockford, IL, USA) and results were measured with a BioTek Epoch 2 microplate spectrophotometer (Winooski, VT, USA). Detailed explanation of these methods is provided in the supporting information.

\section{Results}

\subsection{Cellular Growth in Modified BG11 Media}

Figure 1 summarizes the 14-days evolution of $\mathrm{Abs}_{730}$, cell density and biomass concentration for Anabaena cultured in $\mathrm{BG} 11_{\mathrm{N} 2}, \mathrm{BG} 11_{\mathrm{NO} 3}$, and $\mathrm{BG} 11_{\text {urea }}$ media with different starting Fe levels. The results of fitting growth data to a saturation kinetic model are presented in Figure S3. 


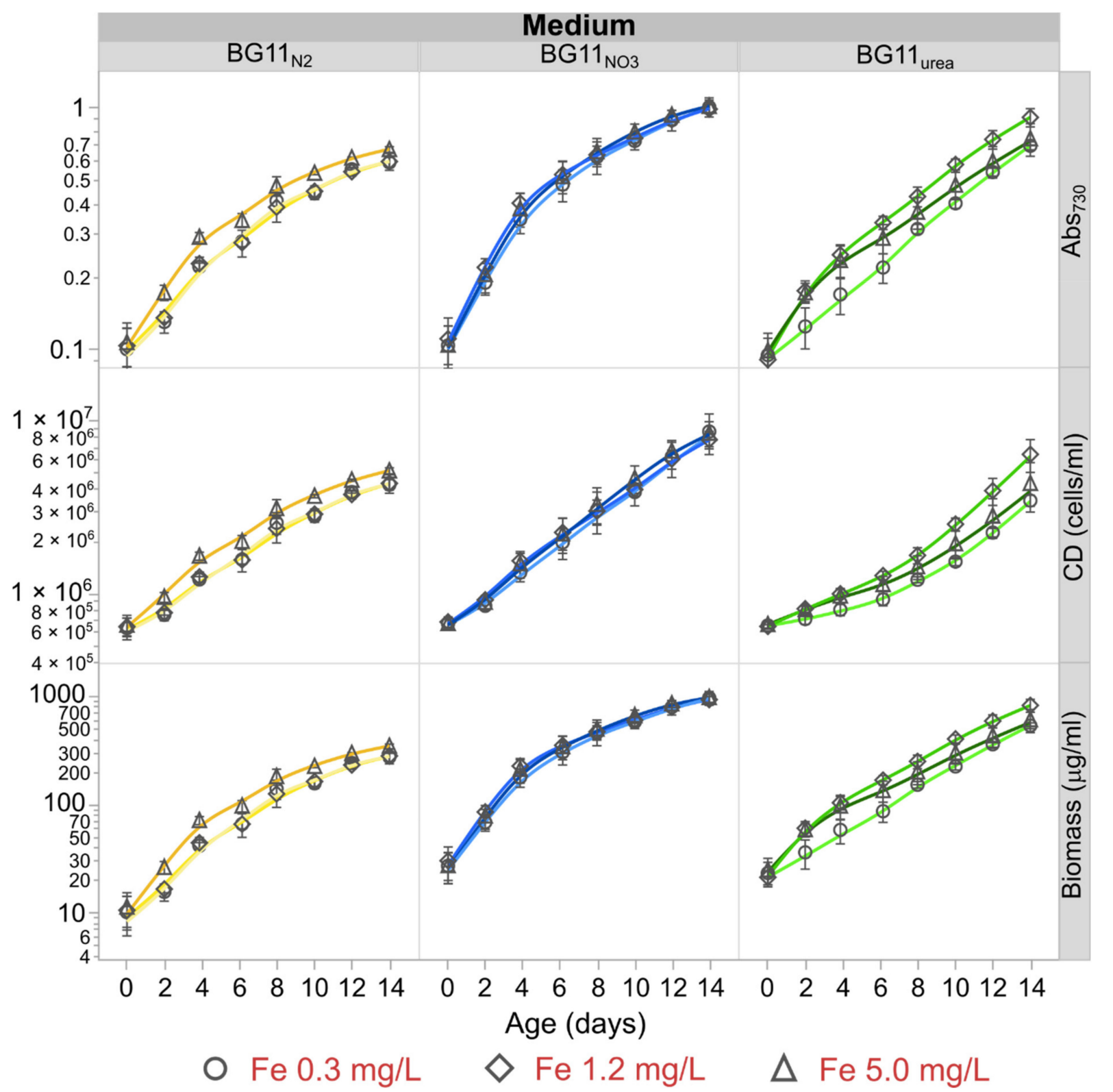

Figure 1. Growth kinetics of Anabaena in $\mathrm{BG} 11_{\mathrm{N} 2}, \mathrm{BG} 11_{\mathrm{NO} 3}$ and $\mathrm{BG} 11_{\text {urea. }}$. Fe concentration did not significantly affect cellular growth in $\mathrm{BG} 11_{\mathrm{NO}}$, but higher biomass generation in $\mathrm{BG} 11_{\text {urea }}$ cultures was observed with initial Fe supply of $1.2 \mathrm{mg} / \mathrm{L}$. High Fe availability (5.0 mg/L) also favored growth and biomass generation in diazotrophic cultures (BG11 $\left.1_{\mathrm{N} 2}\right)$. Overall, cell growth was lowest in BG11 $1_{\mathrm{N} 2}$ medium, while BG11 urea cultures exhibited a longer exponential phase. Slowest growth was observed in BG11 urea with low Fe $(0.3 \mathrm{mg} / \mathrm{L})$. Highest biomass generation was observed in BG11 cultures. Absorbance at $730 \mathrm{~nm}$ was used as indicator of cellular density (second row) and biomass generation over time (third row). Starting nominal $\mathrm{OD}_{730}$ (at day 0) was 0.1 for all cultures. Markers represent average values of three biological replicates and error bars are constructed using one standard error from the mean. Optical densities were measured in triplicate.

\subsection{Effect of $\mathrm{N}$-Source and Fe Levels on Growth Parameters}

The $\mathrm{N}$-source had the most significant effect on the growth rates, generation times and biomass production over 14 days as presented in Table 1 and Figure S4. The chemical properties of fresh media are presented in Tables S3 and S4. On average, growth rates in $\mathrm{BG}_{1} 1_{\mathrm{NO} 3}$ medium were at least $60 \pm 6 \%$ higher than in $\mathrm{BG} 11_{\mathrm{N} 2}$ and $\mathrm{BG} 11_{\text {urea }}$ media $(N=9$ biological replicates per medium type). Remarkably, the average biomass generation of BG11 $1_{\mathrm{NO} 3}$ cultures was more than two times the biomass generation of $\mathrm{BG} 11_{\mathrm{N} 2}$ cultures over two weeks. Although Fe concentration did not significantly impact the growth kinetics 
in $\mathrm{BG} 11_{\mathrm{NO}}$ media, Fe starvation $(0.3 \mathrm{mg} / \mathrm{L})$ significantly reduced the growth rate of cultures in $\mathrm{BG} 11_{\text {urea }}$ by up to $44 \pm 6 \%$. For BG11 ${ }_{\mathrm{N} 2}$ cultures, high Fe availability $(5.0 \mathrm{mg} / \mathrm{L})$ increased the growth rate by $28 \pm 1 \%$. Reduction in growth rates also meant lower biomass generation over 14 days. While cell cultures in $\mathrm{BG} 11_{\mathrm{N} 2}$ and $\mathrm{BG} 11_{\text {urea }}$ media exhibited comparable growth rates, the biomass generation was lowest for diazotrophic filaments in $\mathrm{BG} 11_{\mathrm{N} 2}$. Cultures in $\mathrm{BG} 11_{\mathrm{NO} 3}$ and $\mathrm{BG} 11_{\text {urea }}$ also exhibited brighter green color than BG11 $1_{\mathrm{N} 2}$ cultures (See Figure S5). Growth parameters are summarized in Table 1.

Table 1. Growth and biomass generation of Anabaena in different growth media. Values represent the average and standard errors from three independent biological replicates per Medium-Fe level treatment. Biomass data correspond to the biomass generated over 14 days of growth. Two-way analysis of variance (ANOVA) was used to analyze statistically significant differences with a significance level $\alpha=0.05$. Medium type and Fe-level were used as independent predictors. Medium levels not connected by same group letter are significantly different. Fe-levels not connected by same number of stars within medium type are significantly different. Growth rate (Medium $p$-value $=0.0050 ; \mathrm{Fe}$ level $p$-value $=0.4102$; interaction $p$-value $=0.7536)$, Generation time (Medium $p$-value $=0.0037 ; \mathrm{Fe}$ level $p$-value $=0.1419$; interaction $p$-value $=0.1918)$, biomass-14 days (Medium $p$-value $<0.0001 ; \mathrm{Fe}$ level $p$-value $=0.6376$; interaction $p$-value $=0.5518$ ).

\begin{tabular}{|c|c|c|c|c|c|c|}
\hline $\begin{array}{l}\text { Medium/Fe- } \\
\text { Level }\end{array}$ & $\begin{array}{c}\text { Growth Rate } \\
\left(h^{-1}\right)\end{array}$ & Group & $\begin{array}{c}\text { Generation Time } \\
\text { (h) }\end{array}$ & Group & $\begin{array}{c}\text { Biomass-14 Days } \\
(\mu \mathrm{g} / \mathrm{mL})\end{array}$ & Group \\
\hline a.BG11 ${ }_{\mathrm{N} 2}$ & $0.02 \pm 0.003$ & $\mathrm{~A}$ & $53.59 \pm 7.69$ & $\mathrm{~A}$ & $312.03 \pm 34.24$ & $\mathrm{~A}$ \\
\hline $\mathrm{Fe} 0.3 \mathrm{ppm}$ & $0.018 \pm 0.003$ & * & $57.2 \pm 7.83$ & * & $285.24 \pm 24.94$ & * \\
\hline Fe $1.2 \mathrm{ppm}$ & $0.018 \pm 0.003$ & * & $58.2 \pm 8.76$ & $*$ & $291.91 \pm 45.59$ & * \\
\hline Fe 5.0 ppm & $0.023 \pm 0.004$ & $* *$ & $45.38 \pm 6.91$ & $* *$ & $358.95 \pm 18.05$ & $* *$ \\
\hline b.BG11 $1_{\mathrm{NO} 3}$ & $0.032 \pm 0.006$ & B & $33.61 \pm 5.9$ & B & $772.68 \pm 88.1$ & B \\
\hline Fe 0.3 ppm & $0.031 \pm 0.006$ & * & $34.38 \pm 6.97$ & * & $784.38 \pm 137.21$ & * \\
\hline $\mathrm{Fe} 1.2 \mathrm{ppm}$ & $0.033 \pm 0.006$ & * & $32.6 \pm 5.23$ & * & $746.69 \pm 60.11$ & * \\
\hline Fe 5.0 ppm & $0.033 \pm 0.008$ & * & $33.85 \pm 7.92$ & * & $786.96 \pm 89.99$ & * \\
\hline c.BG11 $1_{\text {urea }}$ & $0.019 \pm 0.004$ & A & $59.87 \pm 13.09$ & $\mathrm{~A}$ & $474.33 \pm 94.18$ & C \\
\hline Fe 0.3 ppm & $0.013 \pm 0.001$ & * & $80.67 \pm 8.78$ & * & $384.46 \pm 28.05$ & * \\
\hline $\mathrm{Fe} 1.2 \mathrm{ppm}$ & $0.024 \pm 0.003$ & $* *$ & $43.91 \pm 7.05$ & $* *$ & $585 \pm 85.7$ & $* *$ \\
\hline Fe $5.0 \mathrm{ppm}$ & $0.021 \pm 0.005$ & $* *$ & $55.04 \pm 14.26$ & $* *$ & $453.52 \pm 130.26$ & * \\
\hline
\end{tabular}

\subsection{Effect of N-Source and Fe Levels on Accumulation of PBPs}

The concentration of CPC, APC, PEC, and total PBPs of each culture was determined and compared with the cell density to determine average abundance of these pigmentprotein complexes per cell over time. Direct measurements of the concentration of PBPs for each medium type and Fe level treatment are summarized in Figure S6. Furthermore, Figure 2 presents the cellular abundance profiles of CPC, APC, PEC, and total PBPs over time. Remarkably, the cellular abundances of all PBPs were higher for BG11 ${ }_{\mathrm{N} 2}$ and BG11 $1_{\text {urea }}$ cultures, especially at low Fe levels. Using day 8 as reference, cells grown in BG11 $1_{\mathrm{N} 2}$ accumulated $31 \pm 3 \%$ more PBPs than $\mathrm{BG} 11_{\mathrm{NO}}$ cells, and cells grown in $\mathrm{BG} 11_{\text {urea }}$ accumulated $44 \pm 6 \%$ more PBPs than BG11 $1_{\mathrm{NO} 3}$ cells (See Table S5). In each growth medium, low Fe-levels had a positive effect on the average accumulation of CPC and APC (Figure 2). Considering data from Table S5, low Fe levels (0.3 mg/L) increased the CPC accumulation by $22 \pm 7 \%, 24 \pm 9 \%$, and $31 \pm 15 \%$ in $\mathrm{BG} 11_{\mathrm{N} 2}, \mathrm{BG} 11_{\mathrm{NO} 3}$, and BG11 1 urea cultures, respectively. Similarly, low Fe-levels $(0.3 \mathrm{mg} / \mathrm{L})$ increased the cellular abundance of $\mathrm{APC}$ by $31 \pm 14 \%, 43 \pm 15 \%$, and $90 \pm 30 \%$ in $\mathrm{BG} 11_{\mathrm{N} 2}, \mathrm{BG} 11_{\mathrm{NO} 3}$, and BG11 $1_{\text {urea }}$ cultures, respectively. Accumulation of PEC was not significantly impacted by the Fe-level in $B G 11_{\mathrm{N} 2}$, nor BG11 ${ }_{\mathrm{NO} 3}$ media. However, low Fe-levels $(0.3 \mathrm{mg} / \mathrm{L})$ were correlated with higher abundance of PEC in BG11 $1_{\text {urea }}$ cultures from day 4 . Figure 2 suggests that APC accumulation is favored in BG11 urea cultures and PEC accumulation is favored in BG11 $\mathrm{N} 2$ cultures. 


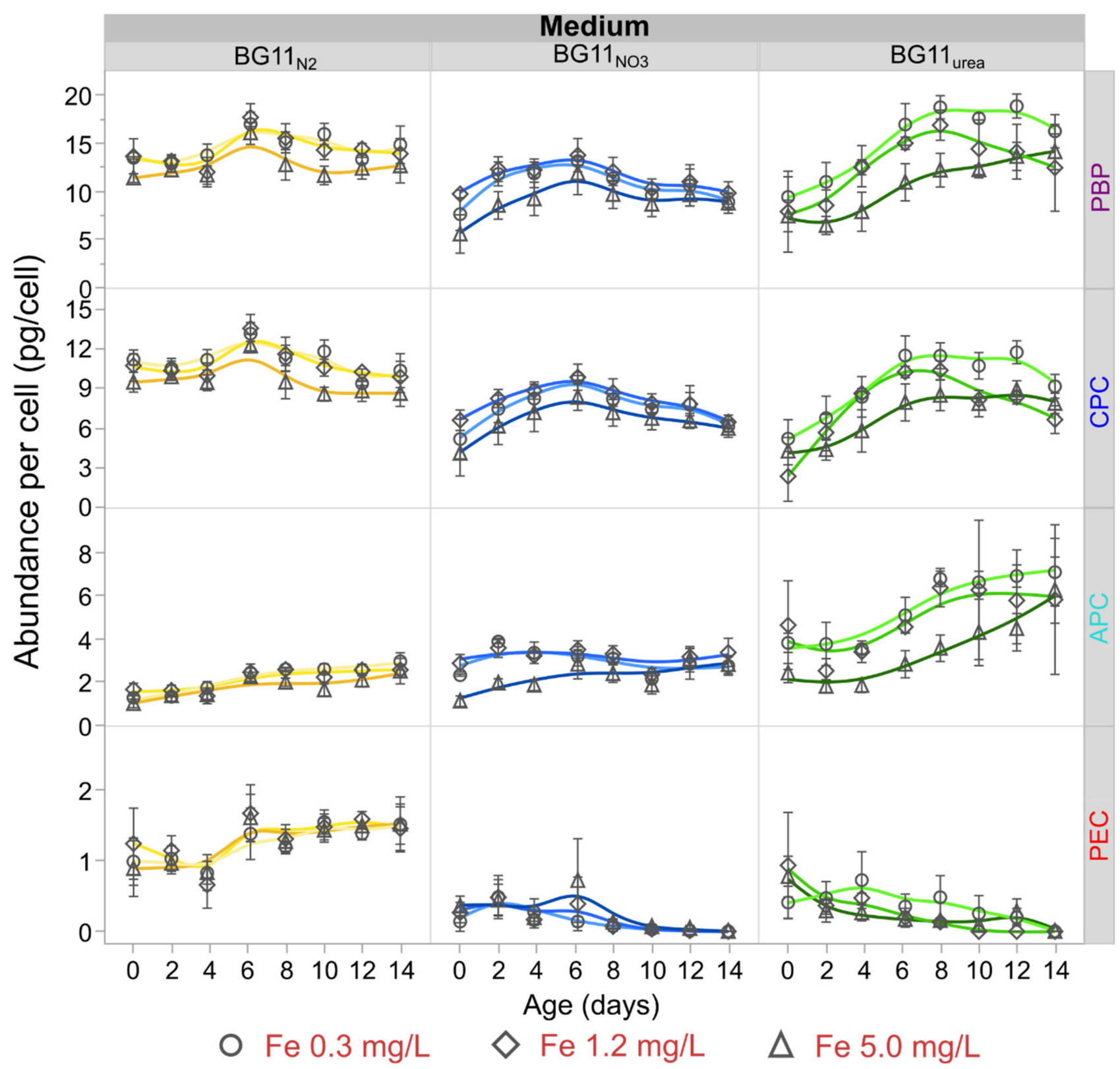

Figure 2. Abundance of phycobiliproteins (PBPs) per cell over time. Cells in BG11 ${ }_{\mathrm{N} 2}$ and $\mathrm{BG} 11_{\mathrm{urea}}$ media presented higher abundances per cell of PBPs, compared to the cultures in BG11 $1_{\mathrm{NO} 3}$. High Fe levels $(5.0 \mathrm{mg} / \mathrm{L})$ led to a statistically significant reduction on the abundance of C-phycocyanin (CPC) and allophycocyanin (APC) accumulation in BG11 $1_{\mathrm{NO}}$ and BG11 $1_{\text {urea }}$ media. The most pronounced reduction in the APC content per cell with increasing Fe was observed for BG11 $1_{\text {urea }}$ cultures. Phycoerythrocyanin (PEC) abundance was higher for diazotrophic BG11 $1_{\mathrm{N} 2}$ cultures. The PEC content in $\mathrm{BG} 11_{\mathrm{NO} 3}$ and BG11 urea was consistently reduced over time, as non-diazotrophic filaments of Anabaena lowered the production of PEC. The highest abundance of APC was registered for low Fe cultures in BG11 urea, specifically at the end of the experiments. Markers represent average values of three independent replicates and error bars are constructed using one standard error from the mean.

\subsection{Effect of N-Source and Fe Levels on Accumulation of Chla and Carotenoids}

Chla and CaroT concentration profiles constructed with cold acetone extraction data are presented in Figure S7. After considering the cell density, relative cellular abundance data for Chla and CaroT are summarized in Figure 3. Cultures in BG11 $1_{\mathrm{NO} 3}$ and $\mathrm{BG} 11_{\text {urea }}$ media exhibited similar profiles, with maximum values of $\mathrm{Chl} a$ and CaroT abundance in the exponential phase (between 4 and 8 days). In contrast, cellular abundances of Chla and CaroT in diazotrophic cells $\left(\mathrm{BG} 11_{\mathrm{N} 2}\right)$ were almost constant. The production rate of $\mathrm{Chl} a$ 
and CaroT in BG11 $1_{\mathrm{N} 2}$ was also constant (Figure S7). Although low Fe-levels $(0.3 \mathrm{mg} / \mathrm{L})$ apparently promoted higher abundance of $\mathrm{Chl} a$ and CaroT in $\mathrm{BG}_{1} 1_{\mathrm{NO} 3}$ and $\mathrm{BG}_{1} 1_{\text {urea }}$ cultures, statistical analysis did not provide definitive evidence to justify a significant effect of Fe-availability on cellular abundance of these hydrophobic pigments (Figure 3 and Table S6). However, the N-source of the growth medium significantly affected the cellular abundance of Chla. Using the average values of Chla abundance on day 4 (Table S6), cultures in BG11 $1_{\text {urea }}$ accumulated around $50 \%$ less Chla than cells grown in $\mathrm{BG}_{1} 1_{\mathrm{NO} 3}$ and

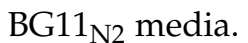

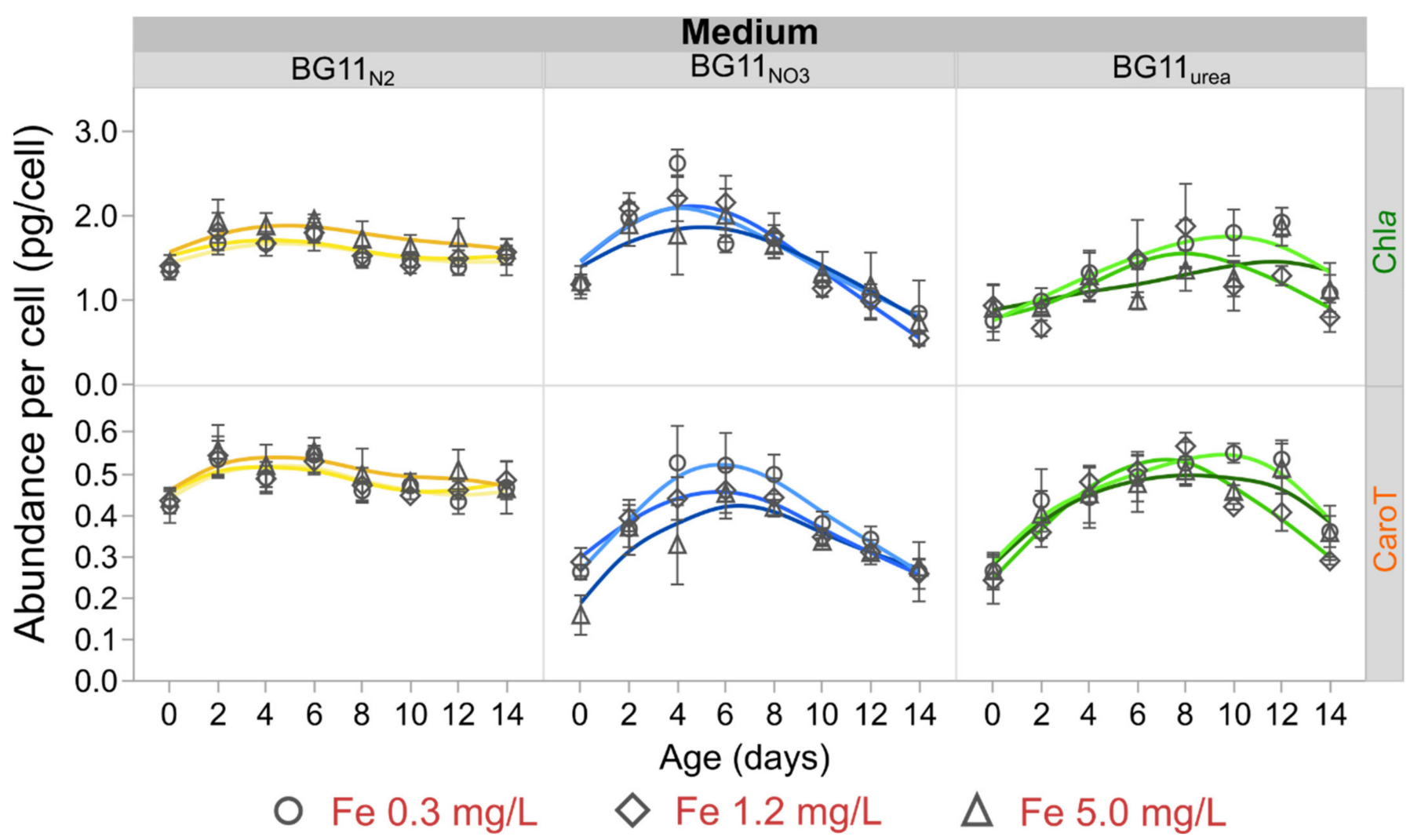

Figure 3. Relative abundance of Chlorophyll $a(\mathrm{Chl} a)$ and total carotenoids (CaroT) per cell. Chla and CaroT profiles were constant in diazotrophic cultures, showing steady production of hydrophobic pigments until the end of the experiment. Non-diazotrophic cultures in $\mathrm{BG} 11_{\mathrm{NO} 3}$ and $\mathrm{BG} 11_{\mathrm{urea}}$ media presented maximum values of Chla and CaroT abundance per cell during their exponential phase. Markers represent average values of three independent replicates and error bars are constructed using one standard error from the mean.

Cold methanol extraction was performed for accurate quantification of $\beta$-carotene using TOF-MS (See Section 2.5). The ion abundance intensity of the $\beta$-carotene peak (molecular ion, $\left[\mathrm{C}_{40} \mathrm{H}_{56}\right]^{+}, \mathrm{m} / \mathrm{z}=536.4382$ ) was compared with the peak intensities of echinenone (protonated molecule, $\left[\mathrm{C}_{40} \mathrm{H}_{54} \mathrm{O}+\mathrm{H}\right]^{+}, \mathrm{m} / \mathrm{z}=551.4253$ ), pheophytin $a$ (protonated molecule, $\left[\mathrm{C}_{55} \mathrm{H}_{74} \mathrm{~N}_{4} \mathrm{O}_{5}+\mathrm{H}\right]^{+}, \mathrm{m} / \mathrm{z}=871.5737$ ) and $\mathrm{Chl} a$ (protonated molecule, $\left.\left[\mathrm{C}_{55} \mathrm{H}_{74} \mathrm{MgN}_{4} \mathrm{O}_{5}+\mathrm{H}\right]^{+}, \mathrm{m} / \mathrm{z}=893.5431\right)$. The $\beta$-carotene abundance per cell and the ratios of relative abundance (as peak intensity ratios) were used to analyze the oxidation of carotenoids in Anabaena. Methanol extraction was performed only for samples on days 6, 10 and 14. A statistical analysis of the data indicated that Fe levels did not have a significant impact on the $\beta$-carotene abundance per cell, at least for $\mathrm{BG}_{1} 1_{\text {urea }}$ and $\mathrm{BG} 11_{\mathrm{NO} 3}$ cultures (Table S6). Therefore, the abundance and oxidation of $\beta$-carotene were analyzed as a function of time and medium type. TOF-MS spectra from Figure S8 correspond to Methanol extractions on day 10 , where the Chla signals for cultures in all media were similar.

Figure 4 summarizes the cellular abundance of $\beta$-carotene in different growth media and compares the echinenone to $\beta$-carotene ratio using peak intensities. Cellular content 
of $\beta$-carotene was higher in younger cultures grown in $\mathrm{BG} 11_{\mathrm{N} 2}, \mathrm{BG} 11_{\mathrm{NO} 3}$, and $\mathrm{BG} 11_{\text {urea }}$ media. Cells grown in BG11 urea exhibited relatively low abundance of $\beta$-carotene during the entire duration of the growth experiments. However, the lowest cellular abundance of $\beta$-carotene was observed for old BG11 $\mathrm{NO}_{\mathrm{NO}}$ cultures (day 14). It was observed that younger cells grown in $\mathrm{BG}_{1} 1_{\mathrm{NO} 3}$ medium presented the lowest echinenone to $\beta$-carotene ratios (days 6 and 10). The echinenone to $\beta$-carotene ratios were significantly higher in cells grown in $\mathrm{BG}_{1} 1_{\mathrm{N} 2}$ and $\mathrm{BG} 11_{\text {urea }}$ media. Figure 4 also presents ratios of relative abundance of $\beta$-carotene to Chla and pheophytin $a$ to Chla. The $\beta$-carotene to Chla ratios were highest for cells in $\mathrm{BG}_{11} 1_{\mathrm{NO} 3}$ medium, specially at the beginning of the growth experiments. Cells grown in BG11 urea medium presented the lowest $\beta$-carotene to Chla ratios. The pheophytin $a$ to Chla ratio was highest for younger cultures in $\mathrm{BG} 11_{\mathrm{NO} 3}$ and lowest for older cells in $\mathrm{BG} 11_{\mathrm{N} 2}$. The ratio of pheophytin $a$ to Chla was similar for cultures in $\mathrm{BG} 11_{\mathrm{N} 2}$ and $\mathrm{BG} 11_{\mathrm{urea}}$, but significantly higher for younger Anabaena cells cultured in $\mathrm{BG}_{1} 1_{\mathrm{NO} 3}$.

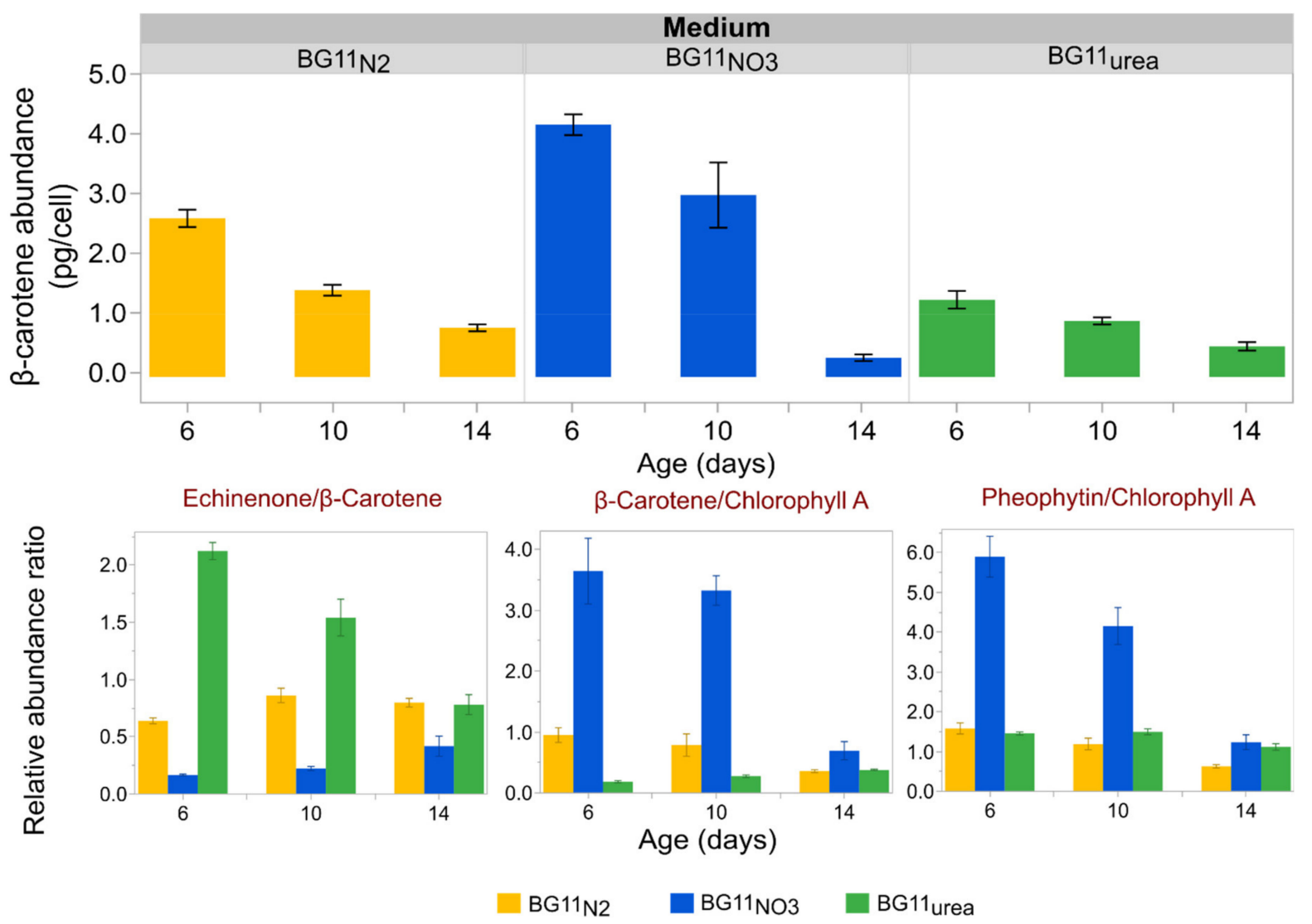

Figure 4. Cellular abundance and oxidation of $\beta$-carotene. Cellular abundance of $\beta$-carotene is reduced over time for $B G 11_{\mathrm{N} 2}$ and $\mathrm{BG} 11_{\mathrm{NO} 3}$ cultures and is lowest for cells grown in BG11 ${ }_{\text {urea }}$ medium (except for day 14). The echinenone to $\beta$-carotene ratio is used as an indicator of $\beta$-carotene oxidation, suggesting that cultures in $B G 11_{\text {urea }}$ are exposed to higher carotene-oxidation levels. The $\beta$-carotene to $\mathrm{Chl} a$ ratio indicates the abundance of non-oxidized carotenoid relative to the abundance of the main photosynthetic pigment. The pheophytin $a$ to Chla ratio is used as an indicator of photosystem II (PSII) integrity. Bars represent the mean of three measurements per sample and each error bar is constructed using one standard error from the mean. Data represent results for six biological replicates per medium type.

\subsection{Consumption Rates of $\mathrm{CO}_{2}$ and $\mathrm{N}$-Sources}

Figure $\mathrm{S} 9$ presents the consumption profiles of $\mathrm{CO}_{2}$ and $\mathrm{N}$-sources in $\mathrm{BG} 11_{\mathrm{N} 2}, \mathrm{BG}_{1} 1_{\mathrm{NO} 3}$, and BG11 $1_{\text {urea }}$ cultures. These results are not presented for different Fe levels because changes in the initial Fe availability did not affect $\mathrm{N}$ or $\mathrm{C}$ demands significantly. $\mathrm{CO}_{2^{-}}$ fixation rates in $\mathrm{BG} 11_{\mathrm{N} 2}, \mathrm{BG} 11_{\mathrm{NO} 3}$, and $\mathrm{BG} 11_{\text {urea }}$ were estimated after fitting the TOC formation data to a zero-order kinetic model. Given that Anabaena cells utilize inorganic 
carbon sources through the carbon concentrating mechanism (CCM), change in TOC is a direct result of atmospheric $\mathrm{CO}_{2}$-hydroxilation or consumption of $\mathrm{Na}_{2} \mathrm{CO}_{3}$ supplied by the growth medium [3]. $\mathrm{CO}_{2}$ consumption rates are directly obtained from the slopes of the straight lines depicted in Figure S9A. Considering molecular weights of $\mathrm{C}$ and $\mathrm{CO}_{2}$ $(12 \mathrm{~g} / \mathrm{mol}$ and $44 \mathrm{~g} / \mathrm{mol})$, a conversion factor of 3.67 was used to convert TOC formation rates to $\mathrm{CO}_{2}$ fixation rates. Consumption data of $\mathrm{N}$-sources were fitted to an apparent first-order reaction model. The first-order rate constant, $k$, can be obtained from the slope of the straight lines presented in Figure S9B. $\mathrm{NO}_{3}$ and urea consumption rate constants equal the absolute value of the corresponding slope. Since fresh BG11 ${ }_{\mathrm{N} 2}$ media contained negligible quantities of elemental $\mathrm{N}$ (Table S3), the $\mathrm{N}_{2}$ fixation rate can be directly obtained from the $\mathrm{N}_{\mathrm{T}}$ slope describing the $\mathrm{N}$-source consumption in $\mathrm{BG} 11_{\mathrm{N} 2}$. Table 2 summarizes $\mathrm{CO}_{2}$ fixation and $\mathrm{N}$-source kinetic parameters for Anabaena cultures. From Table 2, it can be concluded that cells grown in $\mathrm{BG} 11_{\mathrm{NO} 3}$ and $\mathrm{BG} 11_{\text {urea }}$ media (i.e., non-diazotrophic cultures) presented $\mathrm{CO}_{2}$ consumption rates $20 \pm 5 \%$ higher than diazotrophic cultures in $\mathrm{BG} 11_{\mathrm{N} 2}$. Given that urea degradation in the aqueous medium produces $\mathrm{NH}_{4}^{+}$and $\mathrm{HCO}_{3}{ }^{-}$, higher levels of $\mathrm{CO}_{2}$ consumption in $\mathrm{BG} 11_{\text {urea }}$ cultures can also be associated with high urease (EC 3.5.1.5) activity levels in BG11 urea medium (see Figure S10). Higher $\mathrm{CO}_{2}$ consumption rates are also associated with faster consumption of the $\mathrm{N}$-source during the exponential phase for non-diazotrophic cultures. On day 4, the consumption of elemental $\mathrm{N}$ in $\mathrm{BG} 11_{\mathrm{NO} 3}$ was $\sim 6.5$ times the $\mathrm{N}$-consumption in $\mathrm{BG} 11_{\mathrm{N} 2}$. Likewise, the consumption of elemental $\mathrm{N}$ in $\mathrm{BG} 11_{\text {urea }}$ was 3.5 times the $\mathrm{N}$ consumption in $\mathrm{BG} 11_{\mathrm{N} 2}$.

Table 2. Rate constants for $\mathrm{C}$ - and $\mathrm{N}$-source consumption. Total organic carbon (TOC) formation rates represent the zero-order rate constant. $\mathrm{N}$-source consumption is shown in Figure S9. Equivalent $\mathrm{CO}_{2}$ consumption rate was calculated by multiplying TOC formation rate by 3.67. Numbers represent averages and standard deviations for consumption/ fixation rates considering at four biological replicates per medium type and a total of 56 TOC measurements.

\begin{tabular}{|c|c|c|c|}
\hline Formation or Consumption Rates & $\mathrm{BG}^{1} 1_{\mathrm{N} 2}$ & $\mathrm{BG11}_{\mathrm{NO} 3}$ & BG11 $_{\text {urea }}$ \\
\hline TOC formation rate $\left(\mathrm{mg} \mathrm{L}^{-1}\right.$ day $\left.^{-1}\right)$ & $14.5 \pm 1.1$ & $17.2 \pm 0.7$ & $18 \pm 1.3$ \\
\hline $\mathrm{CO}_{2}$ consumption rate $\left(\mathrm{mg} \mathrm{L}^{-1}\right.$ day $\left.^{-1}\right)$ & $53.2 \pm 4$ & $63.1 \pm 2.6$ & $66 \pm 4.8$ \\
\hline $\mathrm{CO}_{2}$ consumption rate $\left(\mathrm{mM}\right.$ day $\left.{ }^{-1}\right)$ & $1.2 \pm 0.09$ & $1.4 \pm 0.06$ & $1.5 \pm 0.11$ \\
\hline N-source consumption rate constant, $k\left(\right.$ day $\left.^{-1}\right)$ & $0.21 \pm 0.013$ & $0.06 \pm 0.004$ & $0.08 \pm 0.012$ \\
\hline N-source consumption rate @ day $4\left(\mathrm{mg} \mathrm{L}^{-1} \text { day }^{-1}\right)^{a}$ & $1.55 \pm 0.1$ & $65.8 \pm 4.4$ & $11.87 \pm 1.8$ \\
\hline N-source consumption rate $@$ day $4\left(\mathrm{mM}\right.$ day $\left.{ }^{-1}\right)$ & $0.06 \pm 0.004$ & $0.77 \pm 0.05$ & $0.2 \pm 0.03$ \\
\hline
\end{tabular}

\subsection{Effect of N-Source and Fe Levels on P Consumption and Micronutrient Utilization}

ICP-OES was used to monitor changes in the concentration of mineral elements in liquid media during cellular growth. For most elements, concentration profiles were converted into consumption profiles after subtracting the element concentration at a given time from their initial concentration in fresh media. This was important for analyzing excess levels of mineral nutrients in the growth media. Figure S11 presents Fe consumption profiles in $B G 11_{\mathrm{N} 2}, \mathrm{BG} 11_{\mathrm{NO} 3}$ and $\mathrm{BG} 11_{\text {urea }}$. Regardless of the initial Fe concentration in the growth media, this element was almost immediately consumed at the beginning of the growth experiments. Figures S12 and S13 present consumption profiles of $\mathrm{P}, \mathrm{Ca}, \mathrm{Mg}, \mathrm{Mn}$, $\mathrm{B}, \mathrm{Mo}, \mathrm{Zn}$, and $\mathrm{Cu}$, suggesting that all these elements were supplied in excess. However, the amount of $\mathrm{P}$ supplied in the growth media was close to exhaustion after 14 days, especially for cultures in $B G 11_{\mathrm{N} 2}$ and $B G 11_{\mathrm{NO} 3}$ media with high Fe levels at the start. The consumption of Mo in BG11 ${ }_{\mathrm{N} 2}$ cultures was also close to exhaustion after 14 days, especially under low and high starting Fe levels. This was expected because Mo is an essential component of nitrogenase (EC 1.18.6.1) [4,8]. Figure S14 presents concentration profiles of $\mathrm{Na}, \mathrm{K}, \mathrm{Ni}$, and $\mathrm{Co}$. These profiles were not converted to consumption data because they did not present significant variations over time in the growth medium. Moreover, the Co level in the growth media was so low that it approached the lower detection limit of the 
method. These consumption profiles suggest that it is possible to adjust the concentrations of micronutrients and minimize excess of these ingredients depending on the duration of each growth experiment. This is important for large-scale continuous operations, where growth medium formulation needs to be optimized.

After considering the number of cells produced at a given time, the consumption profiles of $\mathrm{P}, \mathrm{Ca}, \mathrm{Mg}$, and $\mathrm{Mn}$ per cell are presented in Figure 5. Similar consumption profiles for B, Mo, $\mathrm{Zn}$, and $\mathrm{Cu}$ are summarized in Figure S15. These figures show that the demands for mineral nutrients per cell produced were higher during the exponential phase of culture growth (e.g., up to day 8). Using consumption data for day 4 as a reference (Figure 5 and Table S7), nutrient demands of $\mathrm{P}, \mathrm{Ca}, \mathrm{Mg}$, and $\mathrm{Mn}$ offer additional information. The average $\mathrm{P}$ demand of cells grown in $\mathrm{BG} 11_{\mathrm{NO} 3}$ and $\mathrm{BG} 11_{\mathrm{N} 2}$ media was similar. However, the average $\mathrm{P}$ demand per cell in $\mathrm{BG} 11_{\text {urea }}$ cultures was almost two times the $\mathrm{P}$ demand per cell in BG11 $\mathrm{NO}_{3}$ and $\mathrm{BG}_{1} 1_{\mathrm{N} 2}$ cultures. For all types of media, high Fe level $(5.0 \mathrm{mg} / \mathrm{L})$ also maximized P-consumption per cell. On day 4 , the P consumption per cell in BG11 urea cultures was at least 2.5 times higher with $\mathrm{Fe} 0.3 \mathrm{mg} / \mathrm{L}$ and $\mathrm{Fe} 5.0 \mathrm{pmg} / \mathrm{L}$ compared to Fe $1.2 \mathrm{mg} / \mathrm{L}$. Compared to $\mathrm{BG} 11_{\mathrm{NO} 3}$ and $\mathrm{BG} 11_{\mathrm{N} 2}$ cultures, higher average $\mathrm{Ca}$-demands per cell were observed for cells grown in BG11 urea ( 2 times more) (Table S7). Compared to cultures in BG11 $1_{\text {urea }}$ with Fe $1.2 \mathrm{mg} / \mathrm{L}$, the Ca consumption per cell in BG11 $1_{\text {urea }}$ cultures was $\sim 4.5$ times higher with Fe $0.3 \mathrm{mg} / \mathrm{L}$ and $\sim 5.5$ times with Fe $5.0 \mathrm{pmg} / \mathrm{L}$. Mn consumption increased in all media with Fe $5.0 \mathrm{ppm}$ (See Figure 5). Mg-consumption per cell produced was similar for cultures in $\mathrm{BG} 11_{\mathrm{NO} 3}$ and $\mathrm{BG} 11_{\mathrm{N} 2}$, especially after day 4 . However, the average $\mathrm{Mg}$ demand in $\mathrm{BG}_{1} 1_{\text {urea }}$ cultures was consistently higher than in $\mathrm{BG} 11_{\mathrm{NO}}$ and $B G 11_{\mathrm{N} 2}(\sim 50 \%$ higher on day 4$)$. On BG11 $1_{\text {urea }}$, the highest $\mathrm{Mg}$ demands were consistently observed for cultures with low Fe-level $(0.3 \mathrm{mg} / \mathrm{L})$. High Mn demands were also evident for BG11 $1_{\text {urea }}$ cultures with both low $(0.3 \mathrm{mg} / \mathrm{L})$ and high $(5.0 \mathrm{mg} / \mathrm{L})$ Fe levels. On the other hand, the lowest $\mathrm{Mn}$ demands were observed for $\mathrm{BG}_{1} 1_{\mathrm{NO} 3}$ cultures with medium $(1.2 \mathrm{mg} / \mathrm{L})$ and low $(0.3 \mathrm{mg} / \mathrm{L})$ starting Fe levels. Comparing the data for day 4 , the average Mn-demand of BG11 urea cultures was at least 2.5 times the Mn required by $B{ } 11_{\mathrm{NO} 3}$ and BG11 $1_{\mathrm{N} 2}$ cultures (See Table S7). The Mn consumption in BG11 $1_{\text {urea }}$ is up to 4 times higher than the Mn demand in $\mathrm{BG}_{1} 1_{\mathrm{NO} 3}$ and $\mathrm{BG} 11_{\mathrm{N} 2}$ when only lower Fe levels are considered (Fe $0.3 \mathrm{mg} / \mathrm{L}$ and $\mathrm{Fe} 1.2 \mathrm{mg} / \mathrm{L}$ ). 


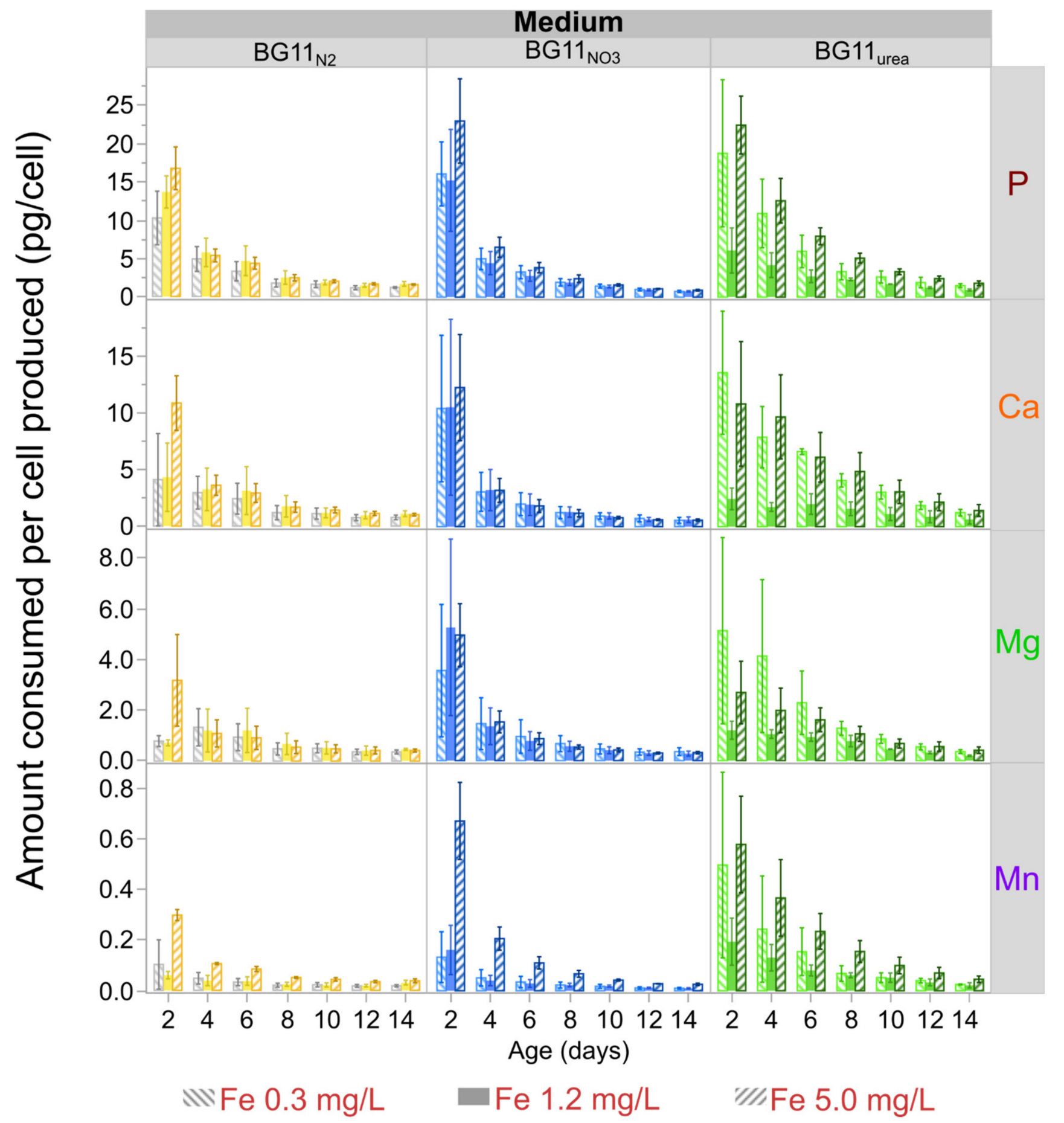

Figure 5. Consumption profiles of $\mathrm{P}, \mathrm{Ca}, \mathrm{Mg}$ and $\mathrm{Mn}$ per cell. The demand of these nutrient elements per cell is pronounced during the early stages of cellular growth. High initial Fe levels maximize the demand of $\mathrm{P}$ and Ca in all growth media. Low initial Fe levels increased Mg and Mn consumption in BG11 urea medium. High starting Fe levels also maximized the consumption of $\mathrm{Mn}$ in $\mathrm{BG}_{11_{\mathrm{N} 2}}$ and $\mathrm{BG} 11_{\mathrm{NO} 3}$ media, probably as a defense strategy against Fe promoted oxidation. Markers represent average values of three independent replicates and error bars are constructed using one standard error from the mean.

\subsection{Ranking of Mineral Elements Utilization}

C- and N-sources are the most important nutrients for cyanobacterial growth. However, it is possible to determine an extended nutrient hierarchy based on the amount of element required per cell produced during the exponential phase. The consumption pro- 
files presented in Figures S12 and S13 were expressed in terms of cells produced instead of time. These profiles were used to estimate element requirements per cell in the exponential phase. Transformed linear regression was used to fit element consumption data to cell density change over time. Regression equations are summarized in Table S8. The derivatives of these expressions with respect to cell density were used to estimate nutrient demands with a reference cell density change of $1 \times 10^{6}$ cells $/ \mathrm{mL}$, which was typical during the first 6 days of growth in all cultures (See Figure 1). Element demands, as well as the effect of starting Fe concentration in each growth media, are summarized in Figure 6. Considering the vast differences in mineral element demands, a logarithmic scale was used to present all nutrient requirements on the same plot.

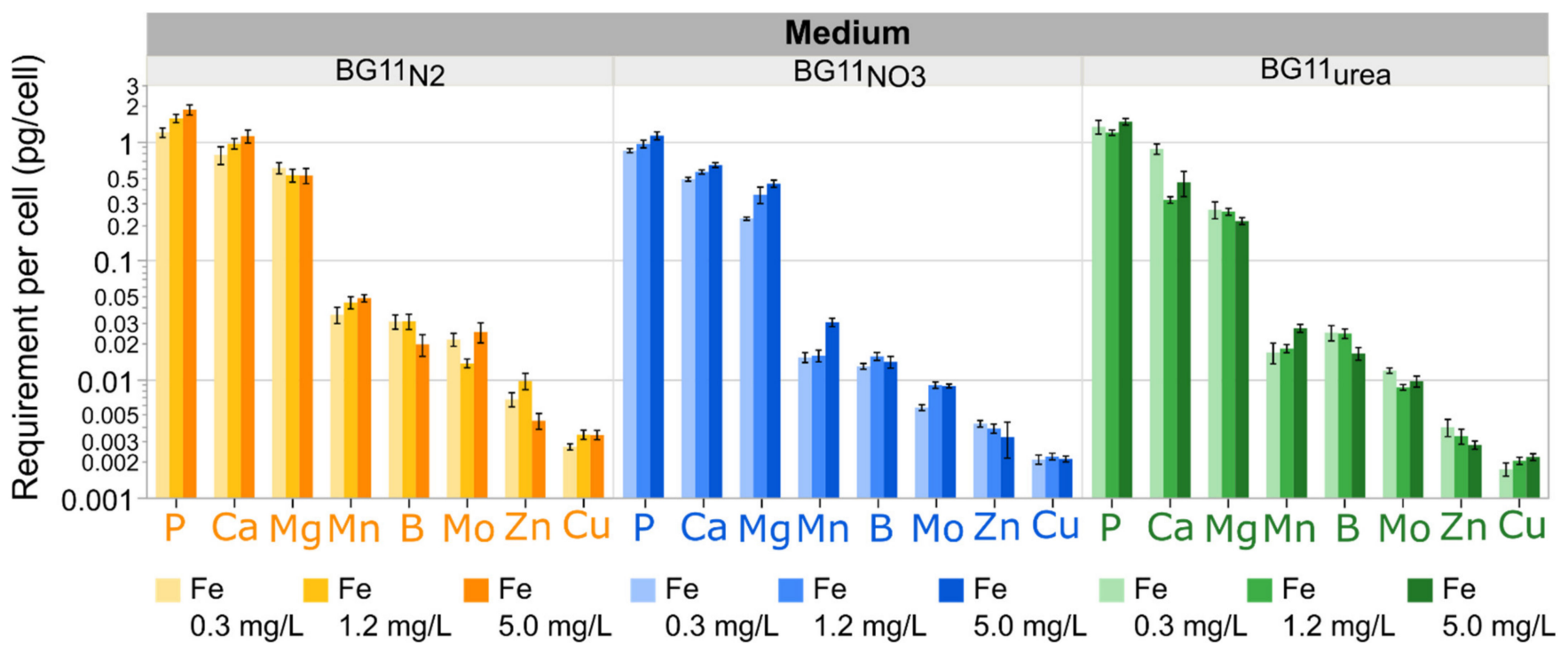

Figure 6. Ranking of mineral element demands per cell. Element demand are calculated based on the cellular production in the exponential phase. $\mathrm{P}, \mathrm{Ca}$ and $\mathrm{Mg}$ are the most important inorganic nutrients, excluding $\mathrm{C}, \mathrm{Fe}$, and $\mathrm{N}$-sources. These elements participate in ATP biosynthesis, cellular signaling and Chla production. Mn is essential for photosynthesis and oxidative stress defense. B and Mo are more important for diazotrophic cells in BG11 $\mathrm{N} 2_{2}$. $\mathrm{Zn}$ and Cu are involved in gene regulation and electron transfer through PSI, respectively. Each bar represents estimated requirements using the derivatives of nutrient consumption expressions with respect to cellular density (Table S8). Error bars represent the confidence fit interval of estimated demands with a significance level $\alpha=0.05$. Actual sizes of the error bars may differ due to the logarithmic scale on the Y-axis. Data represent results for three biological replicates per medium type and Fe level combination.

The effect of varying Fe levels on the consumption of $\mathrm{P}, \mathrm{Ca}$, and $\mathrm{Mg}$ is not similar for all types of media, but $\mathrm{P}$ and Ca requirements per cell increased for BG11 ${ }_{\mathrm{N} 2}$ and BG11 ${ }_{\mathrm{NO} 3}$ cultures with higher Fe levels. While Mg consumption was not evidently affected by Fe levels in $B G 11_{\mathrm{N} 2}$, the requirements of this element were affected in $B G 11_{\mathrm{NO}}$ and BG11 urea media (non-diazotrophic metabolism). These data demonstrate that the mineral nutrient consumption is affected by $\mathrm{N}$ and Fe metabolism in Anabaena, probably because of changing cellular processes during diazotrophic and non-diazotrophic metabolism. A second group of mineral elements is composed by $\mathrm{Mn}, \mathrm{B}$ and Mo. As previously presented, higher Mn demands are associated with increasing Fe-levels in BG11 ${ }_{\mathrm{N} 2}, \mathrm{BG}_{1} 1_{\mathrm{NO} 3}$, and BG11 $1_{\text {urea }}$. Interestingly, B requirements were negatively affected by increasing Fe levels in BG11 $1_{\mathrm{N} 2}$ and BG11 $1_{\text {urea }}$ cultures. Figure 6 successfully captures the amplified importance of $\mathrm{B}$ and $\mathrm{Mo}$ in $\mathrm{BG} 11_{\mathrm{N} 2}$ cultures. $\mathrm{Zn}$ and $\mathrm{Cu}$ appeared at the end of the nutrient consumption ranking. Figure 6 also shows that $Z n$ consumption was lowest with urea in Fe sufficient conditions (BG11 $1_{\text {urea }}$ medium with Fe $1.2 \mathrm{mg} / \mathrm{L}$ and $5.0 \mathrm{mg} / \mathrm{L}$ ). 


\section{Discussion}

\subsection{Faster Growth Rates and Higher Biomass Production Are Observed in $B G 11_{\mathrm{NO} 3}$ Cultures}

Batch cultures of Anabaena were grown in three types of growth medium (i.e., BG11 $1_{\mathrm{N} 2}$, BG11 $1_{\mathrm{NO} 3}$ and $B G 11_{\text {urea }}$ ) using $\mathrm{N}_{2}, \mathrm{NaNO}_{3}$ and urea as $\mathrm{N}$-sources, respectively. While $\mathrm{N}_{2}$ is the most abundant component of the atmosphere, nitrates are the most abundant form of dissolved inorganic $\mathrm{N}$ in surface and deep-water bodies. Urea, a typical component of the urine of mammals, is often used as a fertilizer and is abundant in agro-industrial wastewaters. Ammonium $\left(\mathrm{NH}_{4}{ }^{+}\right)$was not considered because it is rapidly metabolized by multiple microorganisms and it is notably less abundant in water than nitrates [4]. Even when Anabaena cells can successfully metabolize each $\mathrm{N}$-source, differences in growth rates and biomass production suggest that dissimilar metabolic stress phenomena in the growth media affect pigment production and nutrient consumption. Overall, abundance of PBPs and $\beta$-carotene were affected by the $\mathrm{N}$-source and the initial elemental $\mathrm{Fe}$ concentration in Anabaena cultures. While $\mathrm{CO}_{2}$ fixation rates were mostly affected by the medium $\mathrm{N}$ substrate, consumption of phosphorus and micronutrients (e.g., $\mathrm{Ca}, \mathrm{Mn}, \mathrm{B}$, and $\mathrm{Zn}$ ) was also affected by the Fe availability in the growth media.

In this work, the standard formulation of BG11 medium was used as a starting point to design growth media for pigment production in Anabaena because media with high N:P ratios can be used for increased pigment production in microalgae and cyanobacteria [58-60]. Additional details regarding medium formulation are presented in the Supporting Information. For the BG11 urea medium, preliminary experiments were conducted in a medium with $9 \mathrm{mM}$ urea, supplying comparable molar $\mathrm{N}$ levels to $\mathrm{BG}_{11_{\mathrm{NO}}}$ medium [13]. However, such levels of urea led to inconsistent growth kinetics and rapid cellular death. The BG11 urea medium was defined after lowering the urea concentration to $3 \mathrm{mM}$ and including compulsory buffering with TES-NaOH at pH 8.0. Cultivation of Anabaena with urea is not a trivial task, given the increased metabolic stress arising from the utilization of this nutrient [39]. Anabaena cultures were routinely cultivated in the laboratory ensuring complete adaptation

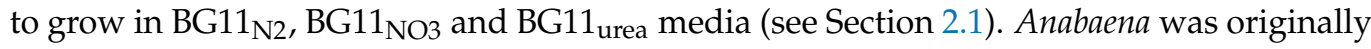
maintained in BG11( $\left.\mathrm{N}^{-}\right)$medium to preserve the heterocyst-forming phenotype, which can be lost over time after prolonged cultivation in N-rich media [61-63]. BG11 $1_{\mathrm{N} 2}$ pre-cultures were directly prepared from diazotrophic cultures in BG11(N-), but BG11 $1_{\mathrm{NO} 3}$ and $\mathrm{BG} 11_{\mathrm{urea}}$ cultures were prepared from precultures that had already been adapted to grow in media with sodium nitrate and urea for more than one month. The presence of heterocysts was verified with optical end electronic microscopy. SEM was used to observe the presence of heterocysts in BG11 $1_{\mathrm{N} 2}$ cultures with more detail (See Figure S1). Although inactive heterocysts can be occasionally found in $\mathrm{N}$ replete cultures (e.g., BG11 $1_{\text {urea }}$ or $B G 11_{\mathrm{NO} 3}$ ), these do not perform $\mathrm{N}_{2}$ fixation because of nitrate and ammonium induced inhibition of nitrogenase [64-67]. The starting Fe levels were selected after considering reports on $\mathrm{Fe}^{3+}$ concentrations that allow cellular growth under Fe-depleted $(0.3 \mathrm{mg} / \mathrm{L})$ and Fe-surplus $(5.0 \mathrm{mg} / \mathrm{L})$ conditions [68]. Although Anabaena can slowly grow in liquid media with 20 to $50 \mathrm{mg} / \mathrm{L}$ of elemental $\mathrm{Fe}$, these organisms are normally grown in mineral medium with Fe $1.2 \mathrm{mg} / \mathrm{L}[13,68,69]$. Maximum growth rates for Anabaena have been reported in culture media with $\mathrm{Fe} 2.8 \mathrm{mg} / \mathrm{L}$ [68]. Given that the growth rates are lower above this concentration, it is implied that the damaging effects of Fe begin to outweigh the benefits of increased $\mathrm{Fe}$ availability. In this study, maximum growth rates were observed for cultures in $\mathrm{BG}_{1} 1_{\mathrm{NO} 3}$ medium, regardless of the Fe level. However, Anabaena cultures in BG11 urea grew faster with starting Fe-levels between 1.2 and $5.0 \mathrm{mg} / \mathrm{L}$. A significant increase in growth rate was observed for BG11 ${ }_{\mathrm{N} 2}$ cultures with Fe $5.0 \mathrm{mg} / \mathrm{L}$, probably because higher $\mathrm{Fe}$ availability favors $\mathrm{N}_{2}$ fixation in diazotrophic cyanobacteria [12]. Higher growth rates were also associated with higher biomass production in Anabaena cultures (highest biomass accumulation in $\mathrm{BG}_{1} 1_{\mathrm{NO} 3}$ cultures). Although similar growth rates were observed in BG11 $1_{\mathrm{N} 2}$ and BG11 $1_{\text {urea, }}$, cell biomass in BG11 $1_{\mathrm{N} 2}$ was significantly lower. This can be explained by the fact that diazotrophic cyanobacteria release exopolysaccharides (EPS) to their surroundings when $\mathrm{N}_{2}$ is used as their main $\mathrm{N}$-source [70,71]. The C: $\mathrm{N}$ ratio of 
$\mathrm{BG} 11_{\mathrm{N} 2}$ media was significantly higher than the $\mathrm{C}: \mathrm{N}$ ratio of $\mathrm{BG} 11_{\mathrm{NO} 3}$ and $\mathrm{BG} 11_{\text {urea }}$ media (Table S3), which can promote carbohydrate production and EPS liberation in Anabaena and Nostoc species [72]. Since released EPS can affect the turbidity of cultures (Abs730), carbohydrate release can also explain the differences in cell density and biomass prediction methods presented for diazotrophic and non-diazotrophic Anabaena (See Figure S2).

\subsection{Low Fe Levels Amplify Accumulation of PBPs}

The cellular abundance of PBPs was higher in $B G 11_{\mathrm{N} 2}$ and $\mathrm{BG} 11_{\text {urea }}$ cultures than in BG1 $11_{\mathrm{NO} 3}$ cultures. On average, $\mathrm{BG} 11_{\mathrm{N} 2}$ cultures developed $31 \pm 2.5 \%$ more PBPs than BG11 ${ }_{\mathrm{NO} 3}$ cultures. Similarly, BG11 $1_{\text {urea }}$ cultures developed $44 \pm 6.5 \%$ more PBPs than BG11 $1_{\mathrm{NO} 3}$ cultures. Cells in $\mathrm{BG} 11_{\mathrm{N} 2}$ and $\mathrm{BG} 11_{\text {urea }}$ also presented slower growth rates. Increased abundance of PBPs in cultures with lower growth rates results from a tradeoff in microbial cellular economics, where slower growth rates are associated with more energetically efficient synthesis of complex molecules [73]. In this regard, higher doubling times allowed the formation of more phycobilisomes (PBSs) before another replication event. The composition of PBPs was also affected by the N-source. Although BG11 ${ }_{\mathrm{N} 2}$ only contained negligible quantities of elemental N (Table S3), heterocysts supplied sufficient levels of $\mathrm{N}_{2}$ fixation to sustain the base $\mathrm{N}$ demand required for diazotrophic metabolism. As a result, $\mathrm{BG} 11_{\mathrm{N} 2}$ cultures effectively produced PBPs, which also act as special N-reserves of cyanobacteria [30]. In average, the PBPs composition of BG11 $1_{\mathrm{N} 2}$ cultures was $\sim 75 \%$ $w / w \mathrm{CPC}, \sim 16 \% w / w$ APC and $\sim 9 \% w / w$ PEC. In BG11 $1_{\mathrm{NO} 3}$ medium, this composition changed to $\sim 73 \% w / w$ CPC, $\sim 28 \%$ w/w APC, and $1 \% w / w$ PEC, exhibiting a dramatic inhibition of PEC biosynthesis. In BG11 1 urea medium, the average PBP composition was $\sim 63 \% w / w$ CPC, $\sim 35 \% w / w$ APC, and $\sim 2 \% w / w$ PEC. These differences in composition are responsible for the changes in cell pigmentation, which are directly associated with the N-source metabolism or the chromatic acclimation mechanisms in the PBSs [30]. The differences in pigmentation of $\mathrm{BG} 11_{\mathrm{NO} 3}, \mathrm{BG} 11_{\mathrm{N} 2}$, and $\mathrm{BG} 11_{\text {urea }}$ cultures are illustrated in Figure S5. While CPC remained the most important PBP in Anabaena, regardless of the $\mathrm{N}$-source, PEC gained importance in $\mathrm{BG} 11_{\mathrm{N} 2}$, and APC abundance increased in BG11 $1_{\text {urea }}$. Considering that PEC is minimized in non-diazotrophic cultures, regardless of the Fe level, diazotrophic Anabaena cultures could be used for large-scale PEC production. In addition, urea-rich wastewater could be used to produce CPC and APC in large-scale operations combining biosynthesis and bioremediation. Although BG11 $1_{\mathrm{NO} 3}$ contained 3 times more elemental $\mathrm{N}$ than BG11 $1_{\text {urea, }}$, the cellular abundance levels of PBPs in these media were similar. This suggests that high N:P ratios in the growth medium do not increase the pigment production indefinitely. Instead, $\mathrm{N}: \mathrm{P} \leq 20$ would be sufficient for efficient large-scale pigment production in Anabaena.

Increasing Fe availability resulted in consistent reduction of the average cellular abundance of CPC and APC in Anabaena cultures. Higher Fe levels reduced the average cellular abundance levels of $\mathrm{CPC}$ and $\mathrm{APC}$ in $\mathrm{BG} 11_{\mathrm{NO} 3}$, at least during the early stages of growth (Figure 2, up to day 10). These results agree with semi-quantitative reverse transcriptionpolymerase chain reaction (PCR) data suggesting downregulation of tetrapyrrole and phycocyanobilin biosynthesis (i.e., the PCB chromophore) in wild-type Anabaena at low levels of FurA redox-sensing transcription factor in Fe replete conditions. Under low Fe availability conditions, high FurA levels increase the transcript abundance of Heme oxygenases I and II (EC 1.14.99.3), promoting the synthesis of PCB, which is the blue pigment of CPC and APC proteins [12]. As cells reproduced over time, Fe became scarcer on a per-cell basis, leading to upregulation of PCB production at later stages of cell growth. In BG $11_{\mathrm{N} 2}$ cultures, CPC abundance was also higher at lower Fe-levels, but PEC and APC abundance values were not affected by changing Fe levels. In BG11 $1_{\text {urea }}$, low Fe levels (initial Fe $0.3 \mathrm{mg} / \mathrm{L}$ ) also amplified the production of PCB, which is the only chromophore in CPC and APC. Low Fe availability generated a remarkable increase of APC accumulation in BG11 $1_{\text {urea. }}$. These results also agree with RNA-Seq experiments presenting transcription levels of genes encoding the subunits $\alpha$ and $\beta$ of APC (alr0021 and alr0022) in Anabaena. 
Transcript abundance of these genes in medium with $\mathrm{NH}_{4}{ }^{+}$, a product of intracellular and extracellular degradation of urea, was two times the transcription level in diazotrophic cells [74-76].

\subsection{Carotenoid Composition Is Related to Oxidative Stress}

The cellular abundance of Chla, CaroT and $\beta$-carotene was principally affected by the $\mathrm{N}$-source in the growth medium. In BG11 $1_{\text {urea }}$, slower Chla production rate (Figure S7) resulted in lower cellular abundance values on the early exponential phase, compared to $\mathrm{BG}_{1} 1_{\mathrm{N} 2}$ and $\mathrm{BG} 11_{\mathrm{NO} 3}$ cultures. In contrast, $\mathrm{Chl} a$ abundance was almost constant in BG11 ${ }_{\mathrm{N} 2}$ cultures. This can be explained because Anabaena have naturally evolved to perform $\mathrm{N}_{2}$ fixation and diazotrophic growth represents the most stable metabolic state. Constant production of Chla in diazotrophic cells has been previously attributed to the chlorophyll regulator (ChlR), which activates Chla biosynthesis in anoxic environments [77-79]. In Anabaena, oxygen-free conditions occur in the heterocysts $\left(\mathrm{N}_{2}\right.$-fixing cells), which are differentiated in $B 111_{\mathrm{N} 2}$ medium $[8,30]$. The cellular abundance of CaroT was highest for BG11 $1_{\mathrm{N} 2}$ cultures (Figure 3 ), but the mean abundance of $\beta$-carotene was lower in BG11 ${ }_{\mathrm{N} 2}$ than in $B G 11_{\mathrm{NO} 3}$ cultures (Figure 4). This suggests that the conversion of $\beta$-carotene into other carotenoids was amplified during diazotrophic growth. $\beta$-Carotene transformation was probably due to oxidation, either induced by light-stress (light-induced oxidative stress at low optical densities) or by excessive generation of free-radicals from unstable metabolic processes.

In Figure 4, oxidation of $\beta$-carotene can be inferred by observing the echinenone/ $\beta$ carotene ratios. Echinenone is the most abundant product of $\beta$-carotene oxidation in Anabaena, mediated by $\beta$-carotene ketolase (EC 1.14.99.63) [33-35]. Therefore, the signal ratios of Echinenone to $\beta$-carotene were used as an indicator of $\beta$-carotene oxidation in different growth media. Based on this, lowest $\beta$-carotene oxidation corresponds to BG11 $1_{\mathrm{NO} 3}$ cultures. On the contrary, the highest $\beta$-carotene oxidation was observed in BG11 urea cultures. This could have occurred because BG11 $1_{\text {urea }}$ cultures presented lower optical and cellular densities during the exponential growth phase (Figure 1), becoming more vulnerable to light-stress events. Higher $\beta$-carotene oxidation in BG11 $1_{\text {urea }}$ cultures is also consistent with previous reports describing that growth on urea as a stressful condition for cyanobacteria, triggering peroxidation and cellular death $[39,80]$. Although the Echinenone to $\beta$-carotene signal ratio decreased over time, this does not necessarily mean a reduction of oxidation levels. Instead, it is possible that other carotenes and xanthophylls are produced by Anabaena in BG11 $1_{\text {urea }}$ medium after continued metabolic stress. This is partially exemplified in Figure S8, where a new peak of significant height $(\mathrm{m} / \mathrm{z}=535.0288)$ was observed only in methanolic extractions from cells in BG11 urea. Further analysis is necessary to identify this, but it might correspond to torulene, which participates in the synthesis of myxoxanthophylls [81,82]. Considering that carotenoid composition analysis of Anabaena have been mostly performed with cells grown in standard BG11 medium with $\mathrm{NaNO}_{3}$ [33-35], further analysis is required to determine differences in the carotenoid composition of diazotrophic and non-diazotrophic cells. One important finding of this study is that the cellular abundance of $\beta$-carotene is negatively affected in Anabaena BG11 $1_{\text {urea }}$ cultures.

Although Chla is the main photosynthetic pigment in PSI and PSII, $\beta$-carotene plays an essential role for light-harvesting and defense against light-induced oxidation $[10,27,36,37]$. Therefore, the $\beta$-carotene to Chla ratio was interpreted as an indicator of photodamage protection in the photosystems. Based on this, $\mathrm{BG} 1_{\mathrm{NO} 3}$ cultures were better protected against photodamage. Exponential phase cellular densities of $\mathrm{BG} 11_{\mathrm{urea}}$ and $\mathrm{BG} 11_{\mathrm{N} 2}$ cultures were lower than cell densities in $\mathrm{BG}_{11_{\mathrm{NO} 3}}$ cultures. This can explain the lower levels of photodamage protection inferred from the $\beta$-carotene to Chla ratios. Cells grown in BG11 urea medium presented the lowest $\beta$-carotene to Chla ratios, which can also be explained by increased $\beta$-carotene oxidation. The pheophytin $a$ to Chla ratio was used as an indicator of Chl $a$ metabolism. Since pheophytin $a$ is Chl $a$ lacking a central $\mathrm{Mg}^{2+}$ atom in the chlorin 
ring [83], it can be observed either as a precursor or as product of chlorophyll breakdown. A more detailed study on the Chla biosynthesis dynamics in Anabaena would be necessary to better explain the high pheophytin $a$ to $\mathrm{Chl} a$ ratios in $\mathrm{BG} 11_{\mathrm{NO} 3}$ cultures. However, it is possible that faster growth rates in $\mathrm{BG}_{11} 1_{\mathrm{NO} 3}$ can be associated with accelerated Chla breakdown or incomplete Chla biosynthesis. This can happen because faster microbial growth rates are associated with less efficient biosynthesis of complex molecules (e.g., Chla) [73]. This could also explain why the pheophytin $a$ to Chla ratios were significantly lower, and closer to unity, in BG11 $1_{\mathrm{N} 2}$ and BG11 urea cultures, which presented slower growth rates than $\mathrm{BG}_{11_{\mathrm{NO} 3}}$ cultures. In general, this analysis suggests that large-scale production of $\beta$-carotene (pro-vitamin A) by Anabaena would be enhanced in growth media with $\mathrm{NaNO}_{3}$.

\subsection{Growth Medium Composition Affects Nutrient Consumption}

Growth media for freshwater cyanobacteria are mainly composed of a nitrogen substrate, phosphates, inorganic carbon, and mineral salts that supply essential metallic micronutrients. While C:N ratios of commonly used media range from 0 to $6.8, \mathrm{~N}: \mathrm{P}$ ratios can be as high as 77 (See Table S1). Excluding Spirulina, which can grow in highly alkaline environments [58], it is common practice to culture freshwater cyanobacteria in growth media with very small quantities of inorganic carbon to promote $\mathrm{CO}_{2}$-fixation from the atmosphere (see Table S2). Although C- and N-sources are the most important nutrients, all the components of the growth medium are used to sustain autotrophic metabolism and cell reproduction. In the end, cyanobacteria are sophisticated microbial photosynthetic bio-factories with simple nutrient requirements, most of which are inorganic compounds. Despite this highly simplified description of the cyanobacterial metabolism, lack and availability of some nutrients have important implications for biomass generation and biotechnological applications of Anabaena. The composition of growth media needs to be properly assessed to standardize cellular reproduction of microorganisms. Although growth requirements for Anabaena cultures are simpler than those of other organisms with biotechnological interest, it is important to learn about nutrient demands in these model cyanobacteria. The consumption rates of $\mathrm{CO}_{2}$ were mostly affected by the type of $\mathrm{N}$-source in the growth medium. These rate constants can be used to determine or validate metabolic constraints for mathematical modeling purposes. In average, $\mathrm{CO}_{2}$ consumption rates of non-diazotrophic Anabaena cultures (BG11 $\mathrm{NO}_{\mathrm{NO}}$ and $\mathrm{BG} 11_{\text {urea }}$ ) were $20 \pm 5 \%$ higher than in diazotrophic cultures $\left(\mathrm{BG}_{1} 1_{\mathrm{N} 2}\right)$. These differences can be explained by higher growth rates in $\mathrm{BG} 11_{\mathrm{NO} 3}$ and higher activity levels of urease in $\mathrm{BG}_{1} 1_{\text {urea }}$. Although Anabaena has evolved to utilize atmospheric $\mathrm{N}_{2}$ as their main $\mathrm{N}$-source, it has been presented that the molar consumption rates of other $\mathrm{N}$-sources (e.g., nitrate and urea) are significantly faster (Table 2). This can be explained because diazotrophic metabolism demands energetically demanding $\mathrm{N}_{2}$-fixation reactions [8], which resulted in a typical diazotrophic growth regime of $B G 11_{\mathrm{N} 2}$ cultures. The exponential-phase $\mathrm{N}_{2}$-fixation rate of $\mathrm{BG} 11_{\mathrm{N} 2}$ Anabaena cultures $\left(0.06 \mathrm{mmol} \mathrm{N}_{2} \mathrm{~L}^{-1}\right.$ day $^{-1}$, Table 2) corresponds to a cellular density of $\sim 1.2 \times 10^{6}$ cells $/ \mathrm{mL}$ (Figure 1, day 4) and Chla concentration of $\sim 2.5 \mu \mathrm{g} / \mathrm{mL}$ (Figure $\mathrm{S7}$, day 4). This translates into a call-specific $\mathrm{N}_{2}$ fixation rate of $3.8 \mathrm{fmol}-\mathrm{N}$ cell ${ }^{-1} \mathrm{~h}^{-1}$ or 0.92 nmol- $\mathrm{N}_{2}(\mu \mathrm{g} \mathrm{Chl} a)^{-1} \mathrm{~h}^{-1}$. These values are comparable to cell-specific $\mathrm{N}_{2}$-fixation rates of $\mathrm{N}_{2}$ fixing cyanobacteria, either cultured under controlled laboratory conditions or in their natural habitats [84-87]. For additional details, refer to Table S10, which compares cell-specific $\mathrm{N}_{2}$ fixation rates for different cyanobacteria.

Besides $\mathrm{C}$ - and $\mathrm{N}$-sources, cyanobacterial growth media contained other mineral elements (e.g., B, Na, Mg, P, K, Ca, Mn, Fe, Co, Ni, Cu, Zn and Mo). From these, the mineral demands of $\mathrm{P}, \mathrm{Ca}, \mathrm{Mg}, \mathrm{Mn}, \mathrm{B}, \mathrm{Mo}, \mathrm{Zn}$, and $\mathrm{Cu}$ were higher during the early exponential phase (Figure 5 and Figure S15). Concentration and consumption profiles of these elements in Anabaena cultures were assessed with a multi-element ICP-OES detection method (Section 2.6). The election of Fe availability as a factor impacting pigment production and nutrient consumption in Anabaena was supported by the vital role of this element in cyanobacteria and its involvement in the dynamic behavior of the master global regulator 
FurA $[7,9-12,16]$. Fe is extremely valuable for cyanobacteria, as occurs for any bacterial species $[10,11]$. Fe consumption profiles presented in Figure S11 indicated that the starting population of Anabaena cells in each culture immediately incorporated this nutrient, activating siderophores and bacterioferritin mediated mechanisms of Fe accumulation $[6,11,88]$. These profiles confirm the fact that cyanobacteria will incorporate as much Fe source as is available in the growth medium [11]. Given that no extra Fe source was added to the cultures during the growth experiments, global Fe concentrations were constant in the batch experiments. Moreover, the initial Fe reserves had to be distributed from mother to daughter cells during reproduction.

Excluding $\mathrm{C}$ - and $\mathrm{N}$-sources, the most important mineral elements in cyanobacterial growth medium are $\mathrm{P}, \mathrm{Ca}, \mathrm{Mg}$, and $\mathrm{Mn}$ (see ranking in Figure 6). This is not surprising because these elements participate in essential metabolic processes. While $\mathrm{P}$ is incorporated in the phosphate groups of ATP, NADPH, DNA, RNA and membrane lipids, Ca plays a pivotal role in cell signaling $[30,89]$. Although $\mathrm{Mg}$ is necessary for the biosynthesis of $\mathrm{Chl} a$, this versatile element is also involved in nucleic acid stabilization, circadian rhythm regulation, DNA replication, ribosomal stabilization, and regulation of RuBisCo (ribulose1,5-bisphosphate carboxylase/oxygenase, EC 4.1.1.39) [10,90,91]. Mn is an essential micronutrient in cyanobacterial growth media because it is present in the $\mathrm{Mn}_{4} \mathrm{CaO}_{5}$ cluster of PSII, which is responsible for $\mathrm{O}_{2}$ evolution and electron transfer from water [22,23]. Remarkably, $\mathrm{Mn}$ is also involved in the defense mechanisms of Anabaena against oxidative stress, as this element is present in Mn catalase (EC 1.11.1.6) and Mn superoxide dismutase (E.C. 1.15.1.1) [92,93]. These enzymes are responsible for the degradation of reactive oxygen species (ROS, i.e., $\mathrm{O}_{2}{ }^{-}$and $\mathrm{H}_{2} \mathrm{O}_{2}$ ) produced during photosynthesis [21,24,25].

Figure 5 indicates that cellular P-demands were initially higher for cultures in $\mathrm{BG}_{\mathrm{N}} 1_{\mathrm{NO}}$ and BG11 $1_{\text {urea }}$. After day 4, the cellular P-demands remained significantly high for BG11 $1_{\text {urea }}$ cultures. Higher P-demands in fast-growing $\mathrm{BG} 11_{\mathrm{NO} 3}$ cultures are understandable because phosphates are essential for synthesis of DNA, RNA, lipids, carbohydrates, and proteins during biomass generation. In $\mathrm{BG} 11_{\text {urea }}$ cultures, higher P demands may be interpreted as a sign of higher enzymatic activity. In general, higher $\mathrm{P}$ demands in non-diazotrophic media, are consistent with several studies dealing with coupled $\mathrm{N}$ and $\mathrm{P}$ consumption in eutrophic waters [94-97]. The lower P demand in BG11 urea with Fe-1.2 mg/L might suggest that these cultures experience lower metabolic stress. In BG11 urea cultures with high $(5.0 \mathrm{mg} / \mathrm{L})$ and low $(0.3 \mathrm{mg} / \mathrm{L})$ initial Fe levels, higher ATP requirements can be related to increased activity of defense mechanisms against peroxidation [39]. Although high Ca demands were observed in BG11 $1_{\text {urea, }}$, increased Ca demands with low and high Fe-levels are not necessarily related to more frequent $\mathrm{Ca}^{2+}$-mediated signaling triggered during cellular stress [89]. While multiple interconnected metabolic processes could explain higher $\mathrm{Mg}$ consumption in non-diazotrophic cells, high Mn demand may be related to increased oxidative stress promoted by ROS in Anabaena [10,12,15]. Low levels of Mn consumption

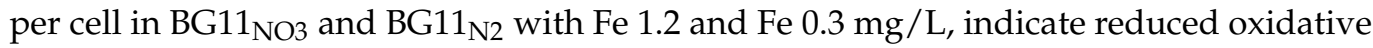
stress when $\mathrm{NaNO}_{3}$ or $\mathrm{N}_{2}$ are used as N-sources. High Mn requirements in $\mathrm{BG}_{1} 1_{\text {urea }}$ cultures can be interpreted as increased levels of oxidative stress (Table S7). Increased Fe availability also amplified Mn requirements for all growth media. Analysis of consumption of other micronutrients in the growth media are presented in the supporting information.

\section{Conclusions}

Selection of a suitable N-source and definition of Fe levels in the growth media are fundamental parameters to analyze pigment production and nutrient consumption by Anabaena cultures. N-source type, Fe availability and oxidative stress events can be manipulated to maximize the efficiency of a desired biotechnological application for Anabaena. While diazotrophic Anabaena cultures can be used for maximum accumulation of phycoerythrocyanin (PEC), growth media with $\mathrm{NaNO}_{3}$ and urea (N:P $\left.\leq 20\right)$ are recommended for C-phycocyaninin (CPC) and allophycocyanin (APC) production, respectively. Here, CPC and APC accumulation was enhanced by low initial Fe levels $(0.3 \mathrm{mg} / \mathrm{L})$. Low oxidative 
stress in growth medium with $\mathrm{NaNO}_{3}$ enhance the bioproduction potential of $\beta$-carotene, a commercially important precursor of vitamin A. For cyanobacteria-mediated bioremediation of wastewater with high loads of urea and phosphates, high oxidative stress could affect the carotenoid composition of non-diazotrophic cultures. Although Anabaena can metabolize multiple $\mathrm{N}$-sources, diazotrophic metabolism $\left(\mathrm{N}_{2}\right.$ fixation) results in most stable production of Chla and higher cellular abundance of phycobiliproteins (PBPs).

$\mathrm{N}$-source type and Fe availability also affected the consumption of mineral elements (e.g., $\mathrm{P}, \mathrm{Ca}, \mathrm{Mg}, \mathrm{Mn}, \mathrm{B}, \mathrm{Mo}, \mathrm{Zn}, \mathrm{Cu}$ ), which play essential roles on the metabolism of cyanobacteria. Controlling the concentration of all nutrients in the growth medium is extremely important for the development of sustainable cyanobacterial biofactories. Therefore, the development of efficient chemical analysis methods for mineral media represents a significant step forward for standardization of cyanobacteria cultivation at a larger scale. Pigments and vitamins are some of the most valuable biotechnological products of cyanobacteria and their biosynthesis is also influenced by the presence of metallic elements and $\mathrm{N}$-sources. Epigenetic interactions between cyanobacteria and metals represent a highly under-explored research field that could complement the field of synthetic biology. The results presented in this paper demonstrate the importance of having a systemic interpretation of the cyanobacterial metabolism to take full advantage of versatile organisms like Anabaena.

Supplementary Materials: The following are available online at https:/ / www.mdpi.com/2076-260 7/9/2/431/s1, Figure S1. SEM picture of diazotrophic filaments of Anabaena; Figure S2. Correlation for estimating Anabaena biomass concentration and cell density from apparent absorbance; Figure S3. Normalized growth data with saturation kinetic model; Figure S4. Growth rates and generation times of Anabaena cultures in different media; Figure S5. Pigmentation of Anabaena cultures; Figure S6. Concentration of PBPs in media with different N-sources; Figure S7. Concentration of Chla and CaroT in different growth media; Figure S8. Mass-spectrometry time-of-flight (MS-TOF) analysis of methanol extracts; Figure S9. Consumption rates of CO2 and N-sources; Figure S10. Anabaena urease activity in different media; Figure S11. Fe consumption profiles in growth media; Figure S12. Consumption profiles of $\mathrm{P}, \mathrm{Ca}, \mathrm{Mg}$ and Mn; Figure S13. Consumption profiles of B, Mo, Zn and $\mathrm{Cu}$; Figure S14. Concentration profiles of $\mathrm{Na}, \mathrm{K}, \mathrm{Ni}$ and $\mathrm{Co}$; Figure S15. Consumption profiles of B, $\mathrm{Mo}, \mathrm{Zn}$ and $\mathrm{Cu}$ per cell; Figure S16. Calibration curve for quantification of $\beta$-carotene; Figure S17. Calibration curve for urea quantification; Figure S18. Inductively coupled plasma optical emission spectroscopy (ICP-OES) calibration for elemental analysis of BG11 media; Table S1. Properties of freshwater and marine growth media for microalgae; Table S2. C:N ratios of growth media used for laboratory and large-scale cultures of cyanobacteria; Table S3. Properties of fresh growth media; Table S4. Concentration of mineral elements in growth media; Table S5. PBPs abundance per cell in different growth media Concentration of mineral elements in growth media; Table S6. Chla, CaroT, and $\beta$-carotene abundance per cell in different growth media; Table S7. P, Ca and Mn requirements per cell produced in different growth media; Table S8. Regression equations for mineral consumption; Table S9. Element concentrations of calibrations standards for ICP-OES; Table S10. $\mathrm{N}_{2}$-fixation rates of diazotrophic cyanobacteria.

Author Contributions: Conceptualization, D.A.N.-C.; methodology, D.A.N.-C.; validation, D.A.N.-C. and T.M.M.; formal analysis, D.A.N.-C. and T.M.M.; investigation, D.A.N.-C. and M.G.B.; resources, M.G.B.; data curation, D.A.N.-C. and T.M.M.; writing-original draft preparation, D.A.N.-C.-review and editing, M.G.B.; visualization, D.A.N.-C.; supervision, M.G.B.; project administration, M.G.B.; funding acquisition, D.A.N.-C. and M.G.B. All authors have read and agreed to the published version of the manuscript.

Funding: This research was funded by Louisiana State University. Daniel A. Norena-Caro was funded, in part, by the Colombian Ministry of Science (Minciencias) and the United States Department of State through the Fulbright-Minciencias fellowship 2015-2019. The APC was funded by the LSU Libraries Open Access Fund and the LSU Cain Department of Chemical Engineering.

Institutional Review Board Statement: Not applicable.

Informed Consent Statement: Not applicable. 
Data Availability Statement: Data is contained within the article or Supplementary Materials. Additional information is available upon request from the corresponding author.

Acknowledgments: We thank Connie David for her valuable support with mass spectrometry methods, Maria Teresa Gutierrez-Wing for supporting TOC measurements, and Kerry Dooley, Natalia Moura, and Behnam Safavinia for their valuable insights to develop a multielement analysis method for mineral media using ICP-OES.

Conflicts of Interest: The authors declare no conflict of interest.

\section{References}

1. Angermayr, S.A.; Gorchs Rovira, A.; Hellingwerf, K.J. Metabolic Engineering of Cyanobacteria for the Synthesis of Commodity Products. Trends Biotechnol. 2015, 33, 352-361. [CrossRef] [PubMed]

2. Martínez-Francés, E.; Escudero-Oñate, C. Cyanobacteria and Microalgae in the Production of Valuable Bioactive Compounds. Microalgal Biotechnol. 2018. [CrossRef]

3. Noreña-Caro, D.; Benton, M.G. Cyanobacteria as Photoautotrophic Biofactories of High-Value Chemicals. J. CO2 Util. 2018, 28, 335-366. [CrossRef]

4. Glass, J.B.; Wolfe-Simon, F.; Anbar, A.D. Coevolution of Metal Availability and Nitrogen Assimilation in Cyanobacteria and Algae. Geobiology 2009, 7, 100-123. [CrossRef]

5. Tiwari, S.; Parihar, P.; Patel, A.; Singh, R.; Prasad, S.M. Metals in Cyanobacteria: Physiological and Molecular Regulation. In Cyanobacteria; Elsevier: Amsterdam, The Netherlands, 2019; pp. 261-276, ISBN 978-0-12-814667-5.

6. Hutchins, D.A.; Rueter, J.G.; Fish, W. Siderophore Production and Nitrogenfixation Are Mutually Exclusive Strategies in Anabaena 712. Limnol. Oceanogr. 1991, 36, 1-12. [CrossRef]

7. López-Gomollón, S.; Hernández, J.A.; Pellicer, S.; Angarica, V.E.; Peleato, M.L.; Fillat, M.F. Cross-Talk Between Iron and Nitrogen Regulatory Networks in Anabaena (Nostoc) Sp. PCC 7120: Identification of Overlapping Genes in FurA and NtcA Regulons. J. Mol. Biol. 2007, 374, 267-281. [CrossRef] [PubMed]

8. Herrero, A.; Flores, E.; Imperial, J. Nitrogen Assimilation in Bacteria. In Reference Module in Life Sciences; Elsevier BV: Amsterdam, The Netherlands, 2019; p. 9780128096338207000.

9. Fillat, M.F. The FUR (Ferric Uptake Regulator) Superfamily: Diversity and Versatility of Key Transcriptional Regulators. Arch. Biochem. Biophys. 2014, 546, 41-52. [CrossRef]

10. Shcolnick, S.; Keren, N. Metal Homeostasis in Cyanobacteria and Chloroplasts. Balancing Benefits and Risks to the Photosynthetic Apparatus. Plant Physiol. 2006, 141, 805-810. [CrossRef]

11. Keren, N.; Aurora, R.; Pakrasi, H.B. Critical Roles of Bacterioferritins in Iron Storage and Proliferation of Cyanobacteria. Plant Physiol. 2004, 135, 1666-1673. [CrossRef] [PubMed]

12. González, A.; Bes, M.T.; Valladares, A.; Peleato, M.L.; Fillat, M.F. FurA Is the Master Regulator of Iron Homeostasis and Modulates the Expression of Tetrapyrrole Biosynthesis Genes in Anabaena Sp. PCC 7120. Environ. Microbiol. 2012, 14, 3175-3187. [CrossRef] [PubMed]

13. Rippka, R.; Deruelles, J.; Waterbury, J.B.; Herdman, M.; Stanier, R.Y. Generic Assignments, Strain Histories and Properties of Pure Cultures of Cyanobacteria. Microbiology 1979, 111, 1-61. [CrossRef]

14. Algal Culturing Techniques; Andersen, R.A. (Ed.) Elsevier/Academic Press: Burlington, MA, USA, 2005; ISBN 978-0-12-088426-1.

15. Touati, D. Iron and Oxidative Stress in Bacteria. Arch. Biochem. Biophys. 2000, 373, 1-6. [CrossRef] [PubMed]

16. González, A.; Bes, M.T.; Peleato, M.L.; Fillat, M.F. Expanding the Role of FurA as Essential Global Regulator in Cyanobacteria. PLoS ONE 2016, 11, e0151384. [CrossRef]

17. Kaushik, M.S.; Singh, P.; Tiwari, B.; Mishra, A.K. Ferric Uptake Regulator (FUR) Protein: Properties and Implications in Cyanobacteria. Ann. Microbiol. 2016, 66, 61-75. [CrossRef]

18. Kaushik, M.S.; Srivastava, M.; Verma, E.; Mishra, A.K. Role of Manganese in Protection against Oxidative Stress under Iron Starvation in Cyanobacterium Anabaena 7120. J. Basic Microbiol. 2015, 55, 729-740. [CrossRef] [PubMed]

19. Blindauer, C.A. Zinc-Handling in Cyanobacteria: An Update. Chem. Biodivers. 2008, 5, 1990-2013. [CrossRef]

20. Bonilla, I.; Garcia-González, M.; Mateo, P. Boron Requirement in Cyanobacteria: Its Possible Role in the Early Evolution of Photosynthetic Organisms. Plant Physiol. 1990, 94, 1554-1560. [CrossRef]

21. Bondarava, N.; Gross, C.M.; Mubarakshina, M.; Golecki, J.R.; Johnson, G.N.; Krieger-Liszkay, A. Putative Function of Cytochrome B559 as a Plastoquinol Oxidase. Physiol. Plant. 2010, 138, 463-473. [CrossRef]

22. Najafpour, M.M.; Moghaddam, A.N.; Shen, J.-R. Govindjee Water oxidation and Water-oxidizing complex in Cyanobacteria. In Stress Biol. of Cyanobacteria; CRC Press/Taylor \& Francis Group: Boca Raton, FL, USA, 2013; pp. 41-60, ISBN 978-1-4665-0478-3.

23. Umena, Y.; Kawakami, K.; Shen, J.-R.; Kamiya, N. Crystal Structure of Oxygen-Evolving Photosystem II at a Resolution of 1.9 A. Nature 2011, 473, 55-60. [CrossRef]

24. Raven, J.A.; Evans, M.C.W.; Korb, R.E. The Role of Trace Metals in Photosynthetic Electron Transport in O2-Evolving Organisms. Photosynth. Res. 1999, 60, 111-150. [CrossRef]

25. Smirnoff, N.; Arnaud, D. Hydrogen Peroxide Metabolism and Functions in Plants. New Phytol. 2019, 221, 1197-1214. [CrossRef] 
26. Jordan, P.; Fromme, P.; Witt, H.T.; Klukas, O.; Saenger, W.; Krauß, N. Three-Dimensional Structure of Cyanobacterial Photosystem I at $2.5 \AA$ Resolution. Nat. Cell Biol. 2001, 411, 909-917. [CrossRef]

27. Shevela, D.; Pishchalnikov, R.Y.; Eichacker, L.A. Govindjee Oxygenic Photosynthesis in Cyanobacteria. In Stress Biology of Cyanobacteria; Srivastava, A.K., Rai, A.N., Neilan, B.A., Eds.; CRC Press/Taylor \& Francis Group: Boca Raton, FL, USA, 2013; pp. 3-40, ISBN 978-1-4665-0478-3.

28. Bussell, A.; Kehoe, D. Chromatic Acclimation: A Many-Coloured Mechanism For Maximizing Photosynthetic Light Harvesting Efficiency. In The Cell Biology of Cyanobacteria; Caister Academic Press: Poole, UK, 2014; ISBN 978-1-908230-38-6.

29. Chang, L.; Liu, X.; Li, Y.; Liu, C.-C.; Yang, F.; Zhao, J.; Sui, S.-F. Structural Organization of an Intact Phycobilisome and Its Association with Photosystem II. Cell Res. 2015, 25, 726-737. [CrossRef]

30. Flores, E.; Herrero, A. Cell Biology of Cyanobacteria; Caister Academic Press: Poole, UK, 2014; ISBN 978-1-908230-92-8.

31. Bryant, D.A.; Glazer, A.N.; Eiserling, F.A. Characterization and Structural Properties of the Major Biliproteins of Anabaena sp. Arch. Microbiol. 1976, 110, 61-75. [CrossRef] [PubMed]

32. Oren, A. Cyanobacteria: Biology, ecology and evolution. In Cyanobacteria; Sharma, N.K., Rai, A.K., Stal, L.J., Eds.; John Wiley \& Sons, Ltd: Chichester, UK, 2014; pp. 1-20, ISBN 978-1-118-40223-8.

33. Mochimaru, M.; Masukawa, H.; Takaichi, S. The Cyanobacterium Anabaena Sp. PCC 7120 Has Two Distinct $\beta$-Carotene Ketolases: CrtO for Echinenone and CrtW for Ketomyxol Synthesis. FEBS Lett. 2005, 579, 6111-6114. [CrossRef]

34. Mochimaru, M.; Masukawa, H.; Maoka, T.; Mohamed, H.E.; Vermaas, W.F.J.; Takaichi, S. Substrate Specificities and Availability of Fucosyltransferase and Beta-Carotene Hydroxylase for Myxol 2'-Fucoside Synthesis in Anabaena Sp. Strain PCC 7120 Compared with Synechocystis Sp. Strain PCC 6803. J. Bacteriol. 2008, 190, 6726-6733. [CrossRef] [PubMed]

35. Takaichi, S.; Mochimaru, M.; Maoka, T.; Katoh, H. Myxol and 4-Ketomyxol 2'-Fucosides, Not Rhamnosides, from Anabaena Sp. PCC 7120 and Nostoc Punctiforme PCC 73102, and Proposal for the Biosynthetic Pathway of Carotenoids. Plant Cell Physiol. 2005, 46, 497-504. [CrossRef] [PubMed]

36. Ramanan, C.; Berera, R.; Gundermann, K.; van Stokkum, I.; Büchel, C.; van Grondelle, R. Exploring the Mechanism(s) of Energy Dissipation in the Light Harvesting Complex of the Photosynthetic Algae Cyclotella Meneghiniana. Biochim. Biophys. Acta (BBA) Bioenerg. 2014, 1837, 1507-1513. [CrossRef] [PubMed]

37. Tóth, T.N.; Chukhutsina, V.; Domonkos, I.; Knoppová, J.; Komenda, J.; Kis, M.; Lénárt, Z.; Garab, G.; Kovács, L.; Gombos, Z.; et al. Carotenoids Are Essential for the Assembly of Cyanobacterial Photosynthetic Complexes. Biochim. Biophys. Acta (BBA) Bioenerg. 2015, 1847, 1153-1165. [CrossRef] [PubMed]

38. Takaichi, S.; Maoka, T.; Mochimaru, M. Unique Carotenoids in the Terrestrial Cyanobacterium Nostoc Commune NIES-24: 2-Hydroxymyxol 2'-Fucoside, Nostoxanthin and Canthaxanthin. Curr. Microbiol. 2009, 59, 413-419. [CrossRef] [PubMed]

39. Sakamoto, T.; Delgaizo, V.B.; Bryant, D.A. Growth on Urea Can Trigger Death and Peroxidation of the Cyanobacterium Synechococcus Sp. Strain PCC 7002. Appl. Environ. Microbiol. 1998, 64, 6. [CrossRef] [PubMed]

40. Latifi, A.; Ruiz, M.; Zhang, C.-C. Oxidative Stress in Cyanobacteria. FEMS Microbiol. Rev. 2009, 33, 258-278. [CrossRef]

41. Latifi, A.; Jeanjean, R.; Lemeille, S.; Havaux, M.; Zhang, C.-C. Iron Starvation Leads to Oxidative Stress in Anabaena sp. Strain PCC 7120. J. Bacteriol. 2005, 187, 6596-6598. [CrossRef] [PubMed]

42. Chakdar, H.; Pabbi, S. Cyanobacterial Phycobilins: Production, Purification, and Regulation. In Frontier Discoveries and Innovations in Interdisciplinary Microbiology; Shukla, P., Ed.; Springer: New Delhi, India, 2016; pp. 45-69, ISBN 978-81-322-2609-3.

43. Bermejo, R. Phycocyanins. In Cyanobacteria; Sharma, N.K., Rai, A.K., Stal, L.J., Eds.; John Wiley \& Sons, Ltd: Chichester, UK, 2014; pp. 209-225, ISBN 978-1-118-40223-8.

44. Hernández, J.A.; Bes, M.T.; Fillat, M.F.; Neira, J.L.; Peleato, M.L. Biochemical Analysis of the Recombinant Fur (Ferric Uptake Regulator) Protein from Anabaena PCC 7119: Factors Affecting Its Oligomerization State. Biochem. J. 2002, 366, $315-322$. [CrossRef]

45. Raja, R.; Hemaiswarya, S.; Carvalho, I.S.; Ganesan, V. Therapeutic applications of cyanobacteria with emphasis on their economics. In Cyanobacteria; Sharma, N.K., Rai, A.K., Stal, L.J., Eds.; John Wiley \& Sons, Ltd: Chichester, UK, 2013; pp. 93-102, ISBN 978-1118-40223-8.

46. Rivera, S.M.; Christou, P.; Canela-Garayoa, R. Identification of Carotenoids Using Mass Spectrometry. Mass Spectrom. Rev. 2014, 33, 353-372. [CrossRef]

47. Amorim-Carrilho, K.T.; Cepeda, A.; Fente, C.; Regal, P. Review of Methods for Analysis of Carotenoids. TrAC Trends Anal. Chem. 2014, 56, 49-73. [CrossRef]

48. Markou, G.; Georgakakis, D. Cultivation of Filamentous Cyanobacteria (Blue-Green Algae) in Agro-Industrial Wastes and Wastewaters: A Review. App. Energy 2011, 88, 3389-3401. [CrossRef]

49. Ahluwalia, S.S.; Goyal, D. Microbial and Plant Derived Biomass for Removal of Heavy Metals from Wastewater. Bioresour. Technol. 2007, 98, 2243-2257. [CrossRef] [PubMed]

50. Azevedo, R.; Rodriguez, E.; Figueiredo, D.; Peixoto, F.; Santos, C. Methodologies for the Study of Filamentous Cyanobacteria by Flow Cytometry. Fresenius Environ. Bull. 2012, 21, 679-684.

51. Lane, C. Bioplastic Production in Cyanobacteria and Consensus Degenerate PCR Probe Design. Ph.D. Thesis, Louisiana State University, Baton Rouge, LA, USA, 2015.

52. Kaplan, D.; Calvert, H.E.; Peters, G.A. The Azolla-Anabaena Azollae Relationship 1. Plant Physiol. 1986, 80, 884-890. [CrossRef] 
53. Lichtenthaler, H.K.; Buschmann, C. Chlorophylls and Carotenoids: Measurement and Characterization by UV-VIS Spectroscopy. Curr. Protoc. Food Anal. Chem. 2001, 1, F4.3.1-F4.3.8. [CrossRef]

54. Britton, G. General carotenoid methods. In Methods in Enzymology; Elsevier: Amsterdam, The Netherlands, 1985; Volume 111, pp. 113-149.

55. Garcia-Pichel, F.; Castenholz, R.W. Characterization and Biological Implications of Scytonemin, a Cyanobacterial Sheath Pigment1. J. Phycol. 1991, 27, 395-409. [CrossRef]

56. Environmental Monitoring Systems Laboratory. Determination of Metals and Trace Elements in Water and Wastes by Inductively Coupled Plasma-Atomic Emission Spectrometry. In Methods for the Determination of Metals in Environmental Samples; Elsevier: Amsterdam, The Netherlands, 1996; pp. 31-87, ISBN 978-0-8155-1398-8.

57. BioVision, Inc. BioVision Urease Activity Assay Kit (Colorimetric) | K378 | . Available online: https://www.biovision.com/ureaseactivity-assay-kit-colorimetric.html (accessed on 7 February 2021).

58. Madkour, F.F.; Kamil, A.E.-W.; Nasr, H.S. Production and Nutritive Value of Spirulina Platensis in Reduced Cost Media. Egypt. J. Aquat. Res. 2012, 38, 51-57. [CrossRef]

59. Mostert, E.S.; Grobbelaar, J.U. The Influence of Nitrogen and Phosphorus on Algal Growth and Quality in Outdoor Mass Algal Cultures. Biomass 1987, 13, 219-233. [CrossRef]

60. Khazi, M.I.; Demirel, Z.; Dalay, M.C. Evaluation of Growth and Phycobiliprotein Composition of Cyanobacteria Isolates Cultivated in Different Nitrogen Sources. Environ. Boil. Fishes 2018, 30, 1513-1523. [CrossRef]

61. Fay, P. Oxygen Relations of Nitrogen Fixation in Cyanobacteria. Microbiol. Rev. 1992, 56, 340-373. [CrossRef] [PubMed]

62. Wang, Y.; Xu, X. Regulation by HetC of Genes Required for Heterocyst Differentiation and Cell Division in Anabaena sp. Strain PCC 7120. J. Bacteriol. 2005, 187, 8489-8493. [CrossRef] [PubMed]

63. Adams, D.G.; Duggan, P.S. Tansley Review No. 107. Heterocyst and Akinete Differentiation in Cyanobacteria. New Phytol. 1999, 144, 3-33. [CrossRef]

64. Kang, R.-J.; Shi, D.-J.; Cong, W.; Cai, Z.-L.; Ouyang, F. Regulation of CO2 on Heterocyst Differentiation and Nitrate Uptake in the Cyanobacterium Anabaena Sp. PCC 7120. J. Appl. Microbiol. 2005, 98, 693-698. [CrossRef] [PubMed]

65. Meeks, J.C.; Wycoff, K.L.; Chapman, J.S.; Enderlin, C.S. Regulation of Expression of Nitrate and Dinitrogen Assimilation by Anabaena Species. Appl. Environ. Microbiol. 1983, 45, 1351-1359. [CrossRef] [PubMed]

66. Herrero, A.; Muro-Pastor, A.M.; Flores, E. Nitrogen Control in Cyanobacteria. J. Bacteriol. 2001, 183, 411-425. [CrossRef] [PubMed]

67. Muro-Pastor, M.I.; Florencio, F.J. Regulation of Ammonium Assimilation in Cyanobacteria. Plant Physiol. Biochem. 2003, 41, 595-603. [CrossRef]

68. Saxena, R.K.; Pandey, P.K.; Bisen, P.S. Physiological and Biochemical Alterations in Anabaena 7120 under Iron Stress. Indian J. Exp. Biol. 2002, 40, 594-599.

69. Stevanovic, M.; Lehmann, C.; Schleiff, E. The Response of the TonB-Dependent Transport Network in Anabaena Sp. PCC 7120 to Cell Density and Metal Availability. Biometals 2013, 26, 549-560. [CrossRef] [PubMed]

70. Moreno, J.; Vargas, M.A.; Olivares, H.; Rivas, J.; Guerrero, M.G. Exopolysaccharide Production by the Cyanobacterium Anabaena Sp. ATCC 33047 in Batch and Continuous Culture. J. Biotechnol. 1998, 60, 175-182. [CrossRef]

71. Vincenzini, M.; de Philippis, R.; Sili, C.; Materassi, R. Studies on Exopolysaccharide Release by Diazotrophic Batch Cultures of Cyanospira Capsulata. Appl. Microbiol. Biotechnol. 1990, 34, 392-396. [CrossRef]

72. Otero, A.; Vincenzini, M. Extracellular Polysaccharide Synthesis by Nostoc Strains as Affected by N Source and Light Intensity. J. Biotechnol. 2003, 102, 143-152. [CrossRef]

73. Molenaar, D.; van Berlo, R.; de Ridder, D.; Teusink, B. Shifts in Growth Strategies Reflect Tradeoffs in Cellular Economics. Mol. Syst. Biol. 2009, 5, 323. [CrossRef] [PubMed]

74. Flaherty, B.L.; van Nieuwerburgh, F.; Head, S.R.; Golden, J.W. Directional RNA Deep Sequencing Sheds New Light on the Transcriptional Response of Anabaena Sp. Strain PCC 7120 to Combined-Nitrogen Deprivation. BMC Genom. 2011, 12. [CrossRef]

75. Veaudor, T.; Cassier-Chauvat, C.; Chauvat, F. Genomics of Urea Transport and Catabolism in Cyanobacteria: Biotechnological Implications. Front. Microbiol. 2019, 10, 2052. [CrossRef] [PubMed]

76. Valladares, A.; Montesinos, M.L.; Herrero, A.; Flores, E. An ABC-Type, High-Affinity Urea Permease Identified in Cyanobacteria. Mol. Microbiol. 2002, 43, 703-715. [CrossRef] [PubMed]

77. Pratte, B.S.; Thiel, T. Homologous Regulators, CnfR1 and CnfR2, Activate Expression of Two Distinct Nitrogenase Gene Clusters in the Filamentous Cyanobacterium Anabaena Variabilis ATCC 29413. Mol. Microbiol. 2016, 100, 1096-1109. [CrossRef]

78. Ludwig, M.; Pandelia, M.-E.; Chew, C.Y.; Zhang, B.; Golbeck, J.H.; Krebs, C.; Bryant, D.A. ChlR Protein of Synechococcus Sp. PCC 7002 Is a Transcription Activator That Uses an Oxygen-Sensitive [4Fe-4S] Cluster to Control Genes Involved in Pigment Biosynthesis. J. Biol. Chem. 2014, 289, 16624-16639. [CrossRef] [PubMed]

79. Tsujimoto, R.; Kamiya, N.; Fujita, Y. Transcriptional Regulators ChlR and CnfR Are Essential for Diazotrophic Growth in Nonheterocystous Cyanobacteria. Proc. Natl. Acad. Sci. USA 2014, 111, 6762-6767. [CrossRef] [PubMed]

80. Sakamoto, T.; Bryant, D.A. Requirement of Nickel as an Essential Micronutrient for the Utilization of Urea in the Marine Cyanobacterium Synechococcus Sp. PCC 7002. Microbes Environ. 2001, 16, 177-184. [CrossRef]

81. Ahrazem, O.; Gómez-Gómez, L.; Rodrigo, M.J.; Avalos, J.; Limón, M.C. Carotenoid Cleavage Oxygenases from Microbes and Photosynthetic Organisms: Features and Functions. Int. J. Mol. Sci. 2016, 17, 1781. [CrossRef] [PubMed] 
82. Graham, J.E.; Bryant, D.A. The Biosynthetic Pathway for Myxol-2' Fucoside (Myxoxanthophyll) in the Cyanobacterium Synechococcus Sp. Strain PCC 7002. J. Bacteriol. 2009, 191, 3292-3300. [CrossRef]

83. Tanaka, R.; Takabayashi, A.; Ito, H.; Tanaka, A. Chlorophyll metabolism in photosynthetic organisms. In Handbook of Porphyrin Science (Volumes 16-20): With Applications to Chemistry, Physics, Materials Science, Engineering, Biology and Medicine; Kadish, K.M., Smith, K.M., Guilard, R., Eds.; World Scientific: Singapore, 2012; Volume 20, pp. 213-242, ISBN 978-981-4462-24-2.

84. Klawonn, I.; Nahar, N.; Walve, J.; Andersson, B.; Olofsson, M.; Svedén, J.B.; Littmann, S.; Whitehouse, M.J.; Kuypers, M.M.M.; Ploug, H. Cell-Specific Nitrogen- and Carbon-Fixation of Cyanobacteria in a Temperate Marine System (Baltic Sea). Environ. Microbiol. 2016, 18, 4596-4609. [CrossRef]

85. Svedén, J.B.; Adam, B.; Walve, J.; Nahar, N.; Musat, N.; Lavik, G.; Whitehouse, M.J.; Kuypers, M.M.M.; Ploug, H. High CellSpecific Rates of Nitrogen and Carbon Fixation by the Cyanobacterium Aphanizomenon Sp. at Low Temperatures in the Baltic Sea. FEMS Microbiol. Ecol. 2015, 91. [CrossRef]

86. Czerny, J.; Barcelos e Ramos, J.; Riebesell, U. Influence of Elevated CO2 Concentrations on Cell Division and Nitrogen FIxation Rates in the Bloom-Forming Cyanobacterium. Biogeosciences 2009, 6, 1865-1875. [CrossRef]

87. Lindblad, P.; Atkins, C.A.; Pate, J.S. N2-Fixation by Freshly Isolated Nostoc from Coralloid Roots of the Cycad Macrozamia Riedlei (Fisch. Ex Gaud.) Gardn. Plant Physiol. 1991, 95, 753-759. [CrossRef] [PubMed]

88. Årstøl, E.; Hohmann-Marriott, M.F. Cyanobacterial Siderophores-Physiology, Structure, Biosynthesis, and Applications. Mar. Drugs 2019, 17, 281. [CrossRef] [PubMed]

89. Bachs, O.; Agell, N. Role of Calcium Ions in Cell Regulation. In Calcium and Calmodulin Function in the Cell Nucleus; Bachs, O., Agell, N., Eds.; Molecular Biology Intelligence Unit; Springer: Berlin/Heidelberg, Germany, 1995; pp. 1-9, ISBN 978-3-662-21686-6.

90. Pohland, A.-C.; Schneider, D. $\mathrm{Mg}^{2+}$ Homeostasis and Transport in Cyanobacteria-At the Crossroads of Bacterial and Chloroplast $\mathrm{Mg}^{2+}$ Import. Biol. Chem. 2019, 400, 1289-1301. [CrossRef]

91. Jeong, Y.M.; Dias, C.; Diekman, C.; Brochon, H.; Kim, P.; Kaur, M.; Kim, Y.-S.; Jang, H.-I.; Kim, Y.-I. Magnesium Regulates the Circadian Oscillator in Cyanobacteria. J. Biol. Rhythms 2019, 34, 380-390. [CrossRef] [PubMed]

92. Priya, B.; Premanandh, J.; Dhanalakshmi, R.T.; Seethalakshmi, T.; Uma, L.; Prabaharan, D.; Subramanian, G. Comparative Analysis of Cyanobacterial Superoxide Dismutases to Discriminate Canonical Forms. BMC Genom. 2007, 8, 435. [CrossRef]

93. Chakravarty, D.; Banerjee, M.; Bihani, S.C.; Ballal, A. A Salt-Inducible Mn-Catalase (KatB) Protects Cyanobacterium from Oxidative Stress. Plant Physiol. 2016, 170, 761-773. [CrossRef] [PubMed]

94. Wofsy, S.C. A Simple Model to Predict Extinction Coefficients and Phytoplankton Biomass in Eutrophic Waters1. Limnol. Oceanogr. 1983, 28, 1144-1155. [CrossRef]

95. Ma, J.; Wang, P.; Wang, X.; Xu, Y.; Paerl, H.W. Cyanobacteria in Eutrophic Waters Benefit from Rising Atmospheric $\mathrm{CO}_{2}$ Concentrations. Sci. Total Environ. 2019, 691, 1144-1154. [CrossRef]

96. Painting, S.J.; Devlin, M.J.; Malcolm, S.J.; Parker, E.R.; Mills, D.K.; Mills, C.; Tett, P.; Wither, A.; Burt, J.; Jones, R.; et al. Assessing the Impact of Nutrient Enrichment in Estuaries: Susceptibility to Eutrophication. Mar. Pollut. Bull. 2007, 55, 74-90. [CrossRef]

97. Asaeda, T.; van Bon, T. Modelling the Effects of Macrophytes on Algal Blooming in Eutrophic Shallow Lakes. Ecol. Model. 1997, 104, 261-287. [CrossRef] 